\title{
Nitrogen and phosphorus enrichment accelerates soil organic carbon loss in alpine grassland on the Qinghai-Tibetan Plateau
}

Ruyi Luo a,b, Jianling Fan a, Weijin Wang c,d, Jiafa Luo e, Yakov Kuzyakov f,g,h, Jin-Sheng $\mathrm{He}^{\mathrm{i}}$, Haiyan Chu ${ }^{\mathrm{a}}$, Weixin Ding ${ }^{\mathrm{a}, *}$

${ }^{a}$ State Key Laboratory of Soil and Sustainable Agriculture, Institute of Soil Science, Chinese Academy of Sciences, Nanjing 210008, China

${ }^{\mathrm{b}}$ University of the Chinese Academy of Sciences, Beijing 10049, China

${ }^{\mathrm{c}}$ Department of Environment and Science, Dutton Park, QLD 4102, Australia

${ }^{\mathrm{d}}$ Environmental Futures Research Institute, Griffith University, Nathan, QLD 4111, Australia

${ }^{\mathrm{e}}$ AgResearch Limited, Ruakura Research Centre, Hamilton 3240, New Zealand ${ }^{\mathrm{f}}$ Agro-Technology Institute, RUDN University, Moscow, Russia

${ }^{\mathrm{g}}$ Department of Soil Science of Temperate Ecosystems, Department of Agricultural Soil Science, University of Göttingen, Büsgenweg 2, Göttingen 37077, Germany

${ }^{\mathrm{h}}$ Soil Science Consulting, 37077 Göttingen, Germany

${ }^{\mathrm{i}}$ College of Urban and Environmental Sciences, Peking University, Beijing 100871, China

* Corresponding author. Institute of Soil Science, Chinese Academy of Sciences, Nanjing 210008, China.

Tel.: +86258688 1527. Fax: + 862586881000 . 
E-mail address: wxding@issas.ac.cn (W. Ding).

\begin{abstract}
Anthropogenic activities have substantially increased soil nutrient availability, which in turn affects ecosystem processes and functions, especially in nutrient-limited ecosystems such as alpine grasslands. Although considerable efforts have been devoted to understanding the responses of plant productivity and community composition to nitrogen $(\mathrm{N})$ and phosphorus $(\mathrm{P})$ enrichment, the nutrient enrichment effects on soil organic carbon (SOC) and microbial functions are not well understood. A four-year field experiment was established to evaluate the influence of continuous $\mathrm{N}$ and $\mathrm{P}$ enrichment on plant growth and SOC content in an alpine grassland of the Qinghai-Tibetan Plateau. The study included four treatments: Control without addition, $\mathrm{N}$ addition, $\mathrm{P}$ addition, and $\mathrm{N}$ plus $\mathrm{P}$ addition. $\mathrm{N}$ addition strongly increased aboveground plant biomass and decreased species richness by promoting growth of the dominant grasses species. In contrast, $\mathrm{N}$ and $\mathrm{P}$ enrichment significantly decreased SOC, especially the recalcitrant organic $C$ content in the surface layer $(0-10 \mathrm{~cm})$ by reducing the slow $\mathrm{C}$ pool and enlarging the active $\mathrm{C}$ pool. Microbial biomass and activities of C-degrading enzymes ( $\beta$-glucosidase, cellulase and polyphenol oxidase) and an N-degrading enzyme (chitinase) increased with nutrient inputs. The $\mathrm{CO}_{2}$ emissions during a $300 \mathrm{~d}$ incubation period were positively correlated with the cellulase and chitinase activities, while the slow $\mathrm{C}$ pool was negatively correlated with the cellulase and polyphenol oxidase activities. Consequently, $\mathrm{N}$ and $\mathrm{P}$
\end{abstract}


enrichment accelerated decomposition of the recalcitrant $\mathrm{C}$ by stimulating microbial growth and increasing enzyme activities, leading to negative impacts on soil $\mathrm{C}$ sequestration. Overall, the results indicate that alpine grassland soils of the Qinghai-Tibetan Plateau may be changing from a $\mathrm{C}$ sink to a $\mathrm{C}$ source under increasing $\mathrm{N}$ and $\mathrm{P}$ availability, and improvement of alpine grassland management through nutrient inputs should consider not only the aboveground biomass for grazing, but also the soil $\mathrm{C}$ sequestration and ecosystem functioning.

Keywords: Alpine grassland; Nutrient enrichment; Aboveground biomass; Species richness; Carbon fractions; Enzyme activity

\section{Introduction}

Nitrogen $(\mathrm{N})$ and phosphorus $(\mathrm{P})$ are the two major growth-limiting elements for plants in most terrestrial ecosystems (Elser et al., 2007; Harpole et al., 2011). In the past century, global $\mathrm{N}$ and $\mathrm{P}$ inputs to ecosystems have been greatly increased by human activities associated with fossil fuel combustion, agricultural fertilization, and dust or ash production (Galloway et al., 2008; Wang et al., 2015). Unlike the massive amounts and multiple pathways of anthropogenic reactive $\mathrm{N}$ inputs, sources of atmospheric $\mathrm{P}$ are rather limited as it is derived primarily from rock weathering and inputs of dust or ash (Mahowald et al., 2008). Thus, the unbalanced anthropogenic $\mathrm{N}$ and $\mathrm{P}$ inputs to the biosphere cause terrestrial ecosystems to move toward more $\mathrm{P}$ limitation (Peñuelas et al., 2013; Li et al., 2016). Increased nutrient availability has 
profound impacts on plant productivity and community composition (Clark and Tilman, 2008; Lebauer and Treseder, 2008; Bobbink et al., 2010), as well as their associated ecosystem functions and terrestrial carbon (C) dynamics (Isbell et al., 2013).

As soil $\mathrm{C}$ is the largest $\mathrm{C}$ pool in the terrestrial biosphere, minor changes in soil $\mathrm{C}$ stocks would result in a significant alteration of atmospheric $\mathrm{CO}_{2}$ concentration and impact the $\mathrm{C}$ cycle feedbacks to climate change (Davidson and Janssens, 2006; Trumbore and Czimczik, 2008). Soil organic C (SOC) is composed of pools of varying chemical complexity with mean residence times ranging from days to years and millennia (Schmidt et al., 2011). SOC is often conceptually divided into two fractions: labile organic $\mathrm{C}$, which includes easily oxidizable $\mathrm{C}$, dissolved organic $\mathrm{C}$ and microbial biomass $\mathrm{C}$, and recalcitrant organic $\mathrm{C}$. Contradictory effects of $\mathrm{N}$ input on SOC content have been reported: some studies found increases in SOC (Frey et al., 2014; Maaroufi et al., 2015), while others found decreases (Mack et al., 2004; Ochoa-Hueso et al., 2013) or insignificant changes (Chen et al., 2015). These differences arise from differences in the ecosystem types studied, the forms and rates of $\mathrm{N}$ fertilizer used, and the experiment duration (see meta-analyses: Liu and Greaver, 2010; Lu et al., 2011). Compared with the well-understood $\mathrm{C}$ and $\mathrm{N}$ interactions in soil, effects of $\mathrm{P}$ on soil $\mathrm{C}$ cycling are less debated and nearly unknown (Bradford et al., 2008; Fornara et al., 2013; Poeplau et al., 2016). The turnover rates of organic C in the distinct fractions may respond differently to changes in nutrient availability (Neff et al., 2002; Li et al., 2014a). Thus, it is pivotal to understand the dynamics of 
SOC and its fractions under nutrient enrichment.

Soil microbes represent a large proportion of the living biomass in grassland ecosystems and have profound effects on terrestrial $\mathrm{C}$ dynamics (van der Heijden et al., 2008; Fierer et al., 2012). Microorganisms produce extracellular enzymes (hydrolases and oxidases) to degrade organic C, N, and P from soil (Sinsabaugh et al., 2009). Extracellular enzyme activities (EEAs) are good indicators of microbial nutrient requirements and soil $\mathrm{C}$ decomposition, yet EEAs mostly depend on nutrient availability (Allison et al., 2008; Sinsabaugh et al., 2009; Burns et al., 2013). The EEAs responses to $\mathrm{N}$ fertilization are contradictory, with studies reporting increases (Jian et al., 2016; Chen et al., 2017), decreases (Sinsabaugh, 2010; Ramirez et al., 2012) or little influence (Keeler et al., 2009). This blurs our understanding of the mechanisms driving the soil EEAs response to $\mathrm{N}$ addition. Soil microbes are often sensitive to $\mathrm{N}$ addition (Nemergut et al., 2008; Treseder, 2008; Fierer et al., 2012;), but little is known about the microbial response to $\mathrm{P}$ addition. Recent studies have shown that $\mathrm{P}$ is important for controlling microbial biomass (Liu et al., 2012), communities (Leff et al., 2015), and activity (Cleveland and Townsend, 2006; Fisk et al., 2015).

The Qinghai-Tibetan Plateau is the largest plateau in the world, with an area of around 2.5 million $\mathrm{km}^{2}$ and an average altitude of $4000 \mathrm{~m}$ above sea level, and is regarded as the third pole (Qiu, 2008). Alpine grasslands in this area have a SOC stock of 7.4-33.5 Pg (Wang et al., 2002; Yang et al., 2008), which is, however, particularly sensitive to climate change and anthropogenic activities (Wang et al., 
2012; Liu et al., 2018). During the past three decades, $\mathrm{N}$ deposition in the Qinghai-Tibetan Plateau has increased to $\sim 10 \mathrm{~kg} \mathrm{~N} \mathrm{ha}^{-1} \mathrm{yr}^{-1}$ (Liu et al., 2013; Zhu et al., 2016). $\mathrm{N}$ and $\mathrm{P}$ fertilization have also been applied to promote grass productivity for grazing and improve the quality of degraded grasslands (Chen et al., 2013; Liu et al., 2018). To date, however, little is known regarding the effects of $\mathrm{N}$ and $\mathrm{P}$ addition on the content and fractions of SOC and enzyme activities related to $\mathrm{C}$ cycling in alpine grasslands.

An $\mathrm{N}$ and $\mathrm{P}$ fertilization experiment was established in typical alpine grassland on the Qinghai-Tibetan Plateau. We hypothesized that $\mathrm{N}$ and $\mathrm{P}$ enrichment would promote plant growth in the alpine grassland, which in turn would increase C input into the soil, with positive feedbacks on SOC content. The objectives of this study were to (1) evaluate whether $\mathrm{N}$ and $\mathrm{P}$ enrichment affected SOC content; and (2) understand the underlying response mechanisms of SOC to $\mathrm{N}$ and $\mathrm{P}$ enrichment in this alpine grassland.

\section{Materials and methods}

\subsection{Site description and soil sampling}

A four-year field experiment was established in May 2011 on a typical alpine grassland at the Haibei Alpine Grassland Ecosystem Research Station (373ㄱN N, $101^{\circ} 12^{\prime} \mathrm{E}$ ) in the northeastern Qinghai-Tibetan Plateau, China. The terrain of the study site is flat and open, with an elevation of $3220 \mathrm{~m}$ a.s.1. and uniform vegetation that had never been fertilized. The region has a continental monsoon climate, with a mean 
annual temperature of $-1.7^{\circ} \mathrm{C}$, ranging from a mean monthly temperature of $-14.8^{\circ} \mathrm{C}$ in January to $9.8^{\circ} \mathrm{C}$ in July, and a mean annual precipitation of $580 \mathrm{~mm}$, more than $80 \%$ of which occurs from May to September (Fang et al., 2014). The soil is classified as Mat-Gryic Cambisol and has a clay loam texture, with a mean depth of $0.65 \mathrm{~m}$. The dominant native plant community consists of Kobresia humilis, Festuca ovina, Elymus nutans, Poa pratensis, Carex scabrirostris, Scripus distigmaticus, Gentiana straminea, Gentiana farreri, Leontop odiumnanum, Blvsmus sinocompressus, Potentilla nivea, and Dasiphora fruticose, and all plant species can be divided into four functional groups: grasses, sedges, legumes, and forbs (Song et al., 2012).

Four treatments were included in the field experiment: control without fertilization (Control), $\mathrm{N}$ amendment $(\mathrm{N}), \mathrm{P}$ amendment $(\mathrm{P})$, and combined $\mathrm{N}$ and $\mathrm{P}$ amendment (NP). A randomized block design was used to arrange the treatments with four replicates (blocks), and each plot measured $6 \mathrm{~m} \times 6 \mathrm{~m}$. The blocks were separated by a 2-m-wide buffer strip, and the plots within each block were separated by a 1-m-wide buffer strip to minimize disturbance from neighboring plots. The $\mathrm{N}$ and $\mathrm{P}$ application rate was $100 \mathrm{~kg} \mathrm{~N} \mathrm{ha}^{-1} \mathrm{yr}^{-1}$ as urea and $50 \mathrm{~kg} \mathrm{P} \mathrm{ha}^{-1} \mathrm{yr}^{-1}$ as triple superphosphate, respectively. The fertilizers were divided into three equal parts and evenly distributed by hand onto the ground surface in the plots after sunset (for higher moisture) at the beginning of June, July and August during the growth season per year.

Surface $(0-10 \mathrm{~cm})$ and subsurface $(10-20$ and $20-40 \mathrm{~cm})$ soil samples were collected using a 5-cm-diameter auger on 27 July 2015 . Five soil cores were randomly 
taken from each plot to make a composite sample. Samples were packed in polyethylene bags, immediately stored in a cooler with ice packs, and shipped to the laboratory. The samples were sieved $(2 \mathrm{~mm})$, and all visible roots, residues, and stones were removed. The fresh soil was stored at $4{ }^{\circ} \mathrm{C}$ and a subsample was air-dried for the analysis of soil properties.

\subsection{Analyses of plant and soil properties}

In each plot, a $0.5 \mathrm{~m} \times 0.5 \mathrm{~m}$ quadrat was randomly selected to harvest the plants in the middle of August 2015. All living vascular plants were sorted into species, and species richness is the number of plant species per $1 \mathrm{~m}^{2}$ quadrat. For aboveground biomass measurements, shoots were clipped at ground level and sorted into four plant functional groups. The roots from three replicate soil cores $(0-40 \mathrm{~cm})$ per plot, collected using a 7-cm-diameter soil auger, were used to measure belowground plant biomass. The aboveground and belowground biomass were determined after drying in the oven at $65^{\circ} \mathrm{C}$ for $48 \mathrm{~h}$.

Soil $\mathrm{pH}$ was measured in a 1:2.5 soil-water suspension after shaking for $30 \mathrm{~min}$. Soil moisture $(\%, \mathrm{w} / \mathrm{w})$ was determined by the gravimetric method after drying at $105^{\circ} \mathrm{C}$ for $24 \mathrm{~h}$. Soil total $\mathrm{N}(\mathrm{TN})$ content was measured by the micro-Kjeldahl method (Carter, 1993). Soil was extracted by shaking for $1 \mathrm{~h}$ with $2 \mathrm{M} \mathrm{KCl}$ in a 1:5 soil-solution ratio, and ammonium $\left(\mathrm{NH}_{4}{ }^{+}\right)$, nitrate $\left(\mathrm{NO}_{3}{ }^{-}\right)$, and dissolved total $\mathrm{N}$ (DTN) concentrations in the extracts were measured on a continuous-flow autoanalyzer (Skalar San ${ }^{++}$, Breda, the Netherlands). Dissolved organic N (DON) was 
calculated as follows: DON $=\mathrm{DTN}-\mathrm{NH}_{4}{ }^{+}-\mathrm{N}-\mathrm{NO}_{3}{ }^{-}-\mathrm{N}$. Available P (AP) and total P (TP) in soil were determined with $\mathrm{NaHCO}_{3}$ extraction and $\mathrm{H}_{2} \mathrm{SO}_{4}-\mathrm{HClO}_{4}$ digestion, respectively, and analyzed using the molybdenum blue method (Murphy and Riley, 1962).

\subsection{Measurement of soil organic C fractions}

SOC was determined by the wet oxidation-redox titration method (Carter, 1993). Dissolved organic C (DOC) was extracted with deionized water in a 1:5 soil-solution ratio and analyzed with a TOC analyzer (Multi N/C 3000, Analytik Jena, Germany). Recalcitrant organic $\mathrm{C}$ (ROC) was measured as the residual $\mathrm{C}$ after $6 \mathrm{M} \mathrm{HCl}$ hydrolysis (Paul et al., 2006). Easily oxidizable C (EOC) was measured as the SOC oxidized in $0.02 \mathrm{M}$ potassium permanganate (Mirsky et al., 2008). Microbial biomass $\mathrm{C}(\mathrm{MBC})$ was determined by the chloroform fumigation-extraction method (Vance et al., 1987), and calculated as DOC differences between fumigated and non-fumigated samples divided by a factor of 0.45 .

\subsection{Enzyme activity analyses}

The $\beta$-glucosidase (EC 3.2.1.21) activity was measured using the method of Tabatabai (1994). Briefly, one g (on an oven-dried basis) of fresh soil plus p-nitrophenyl- $\beta$-D-glucoside and modified universal buffer ( $\mathrm{pH}$ 6.0) were incubated for $1 \mathrm{~h}$ in the dark at $37^{\circ} \mathrm{C}$. Then, $0.5 \mathrm{M} \mathrm{CaCl}_{2}$ and $0.2 \mathrm{M}$ trishydroxymethyl aminomethane-sodium hydroxide $(\mathrm{pH} \mathrm{12)}$ were added. The color intensity of the 
filtered supernatants of p-nitrophenol (pNP) produced was determined using a UV-VIS spectrophotometer (UV-1800, Mapada Instruments Co., Shanghai, China) at $410 \mathrm{~nm}$. The procedure of Schinner and von Mersi (1990) was used to determine the activities of invertase (EC 3.2.1.26) and cellulase (EC 3.2.1.4), using 1.2\% (w/v) sucrose solution and $0.7 \%(\mathrm{w} / \mathrm{v}) \mathrm{CM}$-cellulose solution as substrates, respectively. One g (on an oven-dried basis) of fresh soil plus acetate buffer ( $\mathrm{pH} 5.5)$ and substrate were incubated for $3 \mathrm{~h}$ in the dark at $50^{\circ} \mathrm{C}$. After incubation, the suspensions were filtered, and $1 \mathrm{~mL}$ of the filtrate was used to estimate the amount of reducing sugars (as glucose) using the 3,5-dinitrosalicylic acid method. Polyphenol oxidase (EC 1.10.3.2) activity was measured spectrophotometrically using pyrogallol as the substrate (Guan et al., 1986). One g (on an oven-dried basis) of fresh soil and 1\% pyrogallol were incubated for $2 \mathrm{~h}$ in the dark at $30^{\circ} \mathrm{C}$. After incubation, citrate buffer ( $\mathrm{pH}$ 4.5) and ethyl ether were added to extract the reaction product, and the absorbance of the organic phase was measured at $430 \mathrm{~nm}$. Chitinase (EC 3.2.1.14) activity was determined according to Rodriguez-Kabana et al. (1983). One g (on an oven-dried basis) of fresh soil plus $1 \%(\mathrm{w} / \mathrm{w})$ colloidal chitin suspension and phosphate buffer ( $\mathrm{pH} 6.0)$ were incubated for $18 \mathrm{~h}$ in the dark at $37^{\circ} \mathrm{C}$. After dilution, the amount of $\mathrm{N}$-acetyl-glucosamine (NAG) released was determined at $585 \mathrm{~nm}$ using the p-dimethylaminobenzaldehyde method. Acid phosphatase (EC 3.1.3.2) activity was measured using the method of Guan et al. (1986). One g (on an oven-dried basis) of fresh soil plus disodium phenyl phosphate and modified universal buffer ( $\mathrm{pH}$ 6.5) were incubated for $3 \mathrm{~h}$ in the dark at $37^{\circ} \mathrm{C}$. The suspension were 
centrifuged and filtered, and the buffer and 0.5 M 2,6-dibromoquinonechlorimide were added to facilitate color development. The reaction product as phenol was measured at $600 \mathrm{~nm}$.

Enzyme activities were estimated using controls made by mixing buffer with either soil or substrate solution. The values were corrected by subtracting the combined absorption values for the sample and substrate controls from those of the analytical samples. The activities of invertase and cellulase were expressed in $\mathrm{g}$ glucose (GE) released $\mathrm{kg}^{-1} \mathrm{~h}^{-1}$. The activities of $\beta$-glucosidase, polyphenol oxidase, acid phosphatase and chitinase were expressed in $\mathrm{mg}$ p-nitrophenol (pNP) released $\mathrm{kg}^{-1} \mathrm{~h}^{-1}$, g purpurogallin (PG) released $\mathrm{kg}^{-1} \mathrm{~h}^{-1}$, mg phenol released $\mathrm{kg}^{-1} \mathrm{~h}^{-1}$ and $\mathrm{mg}$ $\mathrm{N}$-acetyl-glucosamine (NAG) released $\mathrm{kg}^{-1} \mathrm{~h}^{-1}$, respectively.

\subsection{Measurement of soil organic C mineralization rate}

SOC mineralization was measured by the $\mathrm{CO}_{2}$ efflux during a $300 \mathrm{~d}$ incubation period under controlled conditions. Fifty grams (on an oven-dried basis) of the sieved ( $2 \mathrm{~mm}$ ) fresh soil was weighed into $1 \mathrm{~L}$ glass jars and pre-incubated for $24 \mathrm{~h}$ at $25^{\circ} \mathrm{C}$. Soil moisture in the jars was adjusted to $60 \%$ water-holding capacity by adding deionized water. Lost water in the jar was supplemented every $3 \mathrm{~d}$ with mini-pipettes during the $300 \mathrm{~d}$ incubation. All jars were covered with plastic wrap with needle-punctured holes to maintain aerobic conditions, and then incubated in the dark at $25^{\circ} \mathrm{C} \cdot \mathrm{CO}_{2}$ emission rates were measured at $1,2,4,6,8,10,13,17,21,25,30,38$, $45,57,71,84,119,149,177,204,234,264$, and 300 d. To measure $\mathrm{CO}_{2}$ emission 
rates, each jar was sealed using an airtight butyl rubber stopper perforated in the center and installed with a Perspex tube. Immediately and $6 \mathrm{~h}$ after closure, $20 \mathrm{~mL}$ headspace gas of the jar was sampled with an airtight syringe to measure the $\mathrm{CO}_{2}$ concentration using a gas chromatograph equipped with a thermal conductivity detector operated at $60^{\circ} \mathrm{C}$ (Agilent 7890, Santa Clara, CA, USA). Standard $\mathrm{CO}_{2}$ was provided by the National Research Center for Certified Reference Materials, Beijing, China. The rates of $\mathrm{CO}_{2}$ emission were calculated assuming a linear change in gas concentrations during the $6 \mathrm{~h}$ measurement period.

The cumulative $\mathrm{CO}_{2}$ emissions from SOC decomposition were fitted with a double exponential model (Xu et al., 2017b):

$C_{\mathrm{t}}=C_{\mathrm{a}} \times\left(1-\mathrm{e}^{-k_{\mathrm{a}} t}\right)+C_{\mathrm{s}} \times\left(1-\mathrm{e}^{-k_{\mathrm{s}} t}\right)$

where $C_{t}$ is the cumulative $\mathrm{CO}_{2}-\mathrm{C}$ mineralized (\% of SOC) by time $t ; C_{\mathrm{a}}$ and $k_{\mathrm{a}}$ are the size and mineralization rate constant of the active $\mathrm{C}$ pool in soil, respectively; and $C_{\mathrm{s}}$ and $k_{\mathrm{s}}$ are the size and mineralization rate constant of the slow $\mathrm{C}$ pool in soil $\left(C_{\mathrm{s}}=\right.$ $\left.100 \%-C_{\mathrm{a}}\right)$, respectively. The half-lives $\left(T_{1 / 2}\right)_{\mathrm{a}}$ and $\left(T_{1 / 2}\right)_{\mathrm{s}}$ of the two pools were obtained by dividing 0.693 by $k_{\mathrm{a}}$ and $k_{\mathrm{s}}$, respectively.

Basal respiration was calculated as the $\mathrm{CO}_{2}$ amount released in the first $24 \mathrm{~h}$ after the pre-incubation divided by the dry mass of soil. The metabolic quotient $\left(\mathrm{qCO}_{2}\right)$ was calculated as the ratio of hourly basal respiration to MBC (Thirukkumaran and Parkinson, 2000).

\subsection{Statistical analyses}

Statistical analyses were performed using the SPSS 19.0 software package for 
Windows (SPSS Inc., Chicago, IL, USA). The data were checked for normality and homogeneity of variance (Levene's test) prior to analysis of variance (ANOVA). Statistically significant differences among treatments were tested using one-way ANOVA followed by the least significant difference test (LSD) at the $5 \%$ level of significance. Linear regression models were used to fit the cumulative $\mathrm{CO}_{2}$ emissions or the size of slow $\mathrm{C}$ pool to enzyme activities. Pearson correlation analysis was performed to explore the relationships between soil organic $\mathrm{C}$ fractions and enzyme activities and between plant properties and soil biogeochemical properties.

\section{Results}

\subsection{Soil biochemical properties and plant properties}

The continuous four-year application of $\mathrm{N}$ and $\mathrm{NP}$ increased soil $\mathrm{NO}_{3}{ }^{-}$and $\mathrm{DON}$ concentrations in the $0-10 \mathrm{~cm}$ depth compared with the Control (Table 1). Similarly, P and NP addition increased soil TP and AP contents. N and/or P additions decreased soil TN content and TN/TP. Soil $\mathrm{pH}$ was not significantly different across the treatments.

$\mathrm{N}$ addition alone or in combination with $\mathrm{P}$ substantially increased aboveground plant biomass, compared with the Control, while $\mathrm{P}$ addition alone did not (Table 2). In contrast, $\mathrm{N}$ and/or $\mathrm{P}$ additions did not affect belowground biomass. Among the four plant functional groups, compared with the Control, the addition of $\mathrm{N}$, regardless of $\mathrm{P}$, increased aboveground biomass of grasses. $\mathrm{N}$ addition alone also increased aboveground biomass of sedges, and in contrast, $\mathrm{P}$ addition, regardless of $\mathrm{N}$, reduced 
aboveground biomass of sedges. The aboveground biomass of legumes and forbs was independent of $\mathrm{N}$ or $\mathrm{P}$ addition. Belowground biomass was correlated positively with soil DOC, $\mathrm{NO}_{3}^{-}$, and DON (Table S1). Aboveground biomass of grasses or forbs was related positively to soil $\mathrm{NO}_{3}^{-}$and $\mathrm{DON}$ or $\mathrm{NO}_{3}^{-}$and $\mathrm{DOC}$, respectively. Aboveground biomass of sedges was correlated negatively with $\mathrm{NH}_{4}^{+}$, TP, and AP in soil. Compared with the Control, $\mathrm{N}$ addition reduced plant species richness (Table 2), which showed a negative correlation with soil $\mathrm{NO}_{3}{ }^{-}$and DON (Table S1).

\subsection{Soil organic C fractions}

The SOC content at the surface $0-10 \mathrm{~cm}$ depth in the Control was $66.7 \mathrm{~g} \mathrm{C} \mathrm{kg}^{-1}$, and significantly decreased to $57.8-61.7 \mathrm{~g} \mathrm{C} \mathrm{kg}^{-1}$, a decrease of $7.5-13.3 \%$, under $\mathrm{N}$ and/or P additions over the four years (Fig. 1). However, nutrient addition did not affect SOC content in the 10-20 and 20-40 cm depths (hereafter only data at the surface $0-10 \mathrm{~cm}$ depth are shown). DOC and EOC contents in soil ranged from 81.2 to $96.7 \mathrm{mg} \mathrm{C} \mathrm{kg}^{-1}$ and from 1.43 to $1.78 \mathrm{~g} \mathrm{C} \mathrm{kg}^{-1}$, respectively (Figs. 2a and b); there were no significant differences among treatments. Soil ROC content was $45.5 \mathrm{~g} \mathrm{C}$ $\mathrm{kg}^{-1}$ in the Control treatment and decreased by $8.7-20.1 \%$ under the $\mathrm{N}, \mathrm{P}$, and NP treatments (Fig. 2c). The proportion of ROC to SOC decreased from $68.3 \%$ under the Control treatment to $61.9-66.0 \%$ under the nutrient input treatments. Compared with the Control, MBC content in the $\mathrm{P}$ and NP soil was slightly increased and significantly enhanced in the soil with $\mathrm{N}$ addition alone (Fig. 2d). SOC was positively correlated with EOC and ROC $(P<0.01)$, and negatively related to $\mathrm{MBC}$, albeit not 
significantly $(P=0.113)$.

\subsection{Soil $\mathrm{CO}_{2}$ emissions, $C$ pools, and microbial metabolic quotient}

There was a similar temporal pattern of soil $\mathrm{CO}_{2}$ efflux among the four fertilization treatments during the $300 \mathrm{~d}$ incubation, with a $\mathrm{CO}_{2}$ peak on day 2 (Fig. S1). The $\mathrm{CO}_{2}$ efflux peak in the Control treatment was $83 \mathrm{mg} \mathrm{C} \mathrm{kg}^{-1} \mathrm{~h}^{-1}$, which was lower than those under $\mathrm{N}$ and/or $\mathrm{P}$ additions $(P<0.05)$. Cumulative $\mathrm{CO}_{2}$ emissions during the incubation were ranked $\mathrm{NP}\left(5.68 \mathrm{~g} \mathrm{C} \mathrm{kg}^{-1}\right)>\mathrm{N}\left(5.15 \mathrm{~g} \mathrm{C} \mathrm{kg}^{-1}\right)>\mathrm{P}(5.06 \mathrm{~g}$ $\left.\mathrm{C} \mathrm{kg}^{-1}\right)>$ Control $\left(4.64 \mathrm{~g} \mathrm{C} \mathrm{kg}^{-1}\right)$, which accounted for $7.0-9.2 \%$ of SOC. Compared with the Control, the mineralized SOC in nutrient input soils was enhanced by 9.0-22.4\%. A double exponential model showed that additions of $\mathrm{N}$ and/or $\mathrm{P}$ increased the soil active $\mathrm{C}$ pool, and in contrast, reduced the slow $\mathrm{C}$ pool (Table 3). The half-life of the slow $\mathrm{C}$ pool was consistently shortened in the nutrient addition treatments compared with the Control. In addition, amendments of $\mathrm{P}$ (P and NP) increased $\mathrm{qCO}_{2}$ by $16.4-20.5 \%$ (Table 1 ).

\subsection{Soil enzyme activities}

$\mathrm{N}$ and/or $\mathrm{P}$ additions altered soil enzyme activities, but the effects were enzyme type dependent (Fig. 3). Compared with the Control, $\mathrm{N}$ and/or $\mathrm{P}$ additions increased the activities of chitinase and cellulase by $17.6-67.6 \%$ and $103.8-108.1 \%$, respectively. $\mathrm{N}$ amendments $(\mathrm{N}$ and $\mathrm{NP}$ ) rather than $\mathrm{P}$ alone also increased the activity of $\beta$-glucosidase by $3.9-27.7 \%$. The polyphenol oxidase activity was $23.3-66.7 \%$ 
higher in the N, NP, and especially P treatments compared with the Control. However, no remarkable differences in the activities of acid phosphatase and invertase were found among the treatments. Cellulase activity was negatively correlated with SOC and ROC, and polyphenol oxidase activity was also negatively correlated with SOC (Table 4). The cumulative $\mathrm{CO}_{2}$ emissions were positively correlated with chitinase and cellulase activities $(P<0.001)$ (Fig. 4). The size of the slow $\mathrm{C}$ pool linearly decreased with increasing cellulase and polyphenol oxidase activities $(P<0.001)$ (Fig. $5)$.

\section{Discussion}

\subsection{Effects of $N$ and $P$ enrichment on plant growth}

$\mathrm{N}$ addition alone or in combination with $\mathrm{P}$, but not $\mathrm{P}$ addition alone, increased aboveground plant biomass in alpine grassland ecosystems on the Qinghai-Tibetan Plateau (Table 2), indicating that $\mathrm{N}$ is a key limiting nutrient for plant productivity (Elser et al., 2007; Lebauer and Treseder, 2008). Compared with the unfertilized plots, the average increase of $53.4 \%$ in aboveground biomass under $\mathrm{N}$ fertilization was much higher than the average increase of $29.0 \%$ in most ecosystems across the globe (Lebauer and Treseder, 2008), probably because the amount of the $\mathrm{N}$ addition is higher than the global average. We found that the rate of increase of vascular sedges biomass was higher than that of grasses in the $\mathrm{N}$ treatment $(71.2 \%$ versus $53.8 \%)$, indicating that the present $\mathrm{N}$ addition level increased sedges growth more efficiently although sedges biomass only accounted for $6.0 \%$ of total biomass in the alpine 
grassland ecosystem. In contrast, $\mathrm{P}$ addition, regardless of $\mathrm{N}$ addition, suppressed sedges growth. It has been found that plants with high $\mathrm{N}$ uptake competition, such as Molinia, also need high available $\mathrm{P}$ under $\mathrm{N}$ amendment compared with plants with low competition for $\mathrm{N}$, such as Rhynchospora, and low soil $\mathrm{P}$ availability more easily curbs the expansion of Molinia (Limpens et al., 2003). The dominant grasses species have greater nutrient acquisition ability through advanced physiological and morphological properties of the roots (Wang et al., 2012) and high arbuscular mycorrhizal colonization of their roots in this alpine region (Xu et al., 2011) compared to other plant functional groups. Thus, we postulated that grasses had a relatively high $\mathrm{N}$ uptake potential compared with sedges, and $\mathrm{P}$ addition more efficiently increased the $\mathrm{N}$ uptake capacity of grasses, consequently suppressing the growth of sedges. However, further studies are required to understand the competition between grasses and sedges at increasing $\mathrm{N}$ and $\mathrm{P}$ addition levels.

Plant species richness was reduced following $\mathrm{N}$ addition and was negatively correlated with soil $\mathrm{NO}_{3}$ and $\mathrm{DON}$ (Tables 2 and $\mathrm{S} 1$ ). This suggested that $\mathrm{N}$ enrichment stimulated the expansion of nitrophilous species, which capitalized on the high $\mathrm{N}$ supply and competitively excluded other species (Bobbink et al., 2010). Similarly, Song et al. (2012) reported that high $\mathrm{N}$ addition at $75 \mathrm{~kg} \mathrm{~N} \mathrm{ha}^{-1} \mathrm{yr}^{-1}$ increased aboveground biomass and decreased species richness in an alpine meadow. This was due to increasing aboveground biomass, coverage, and litter accumulation of grasses, which resulted in a decrease of light penetration into the plant canopy, and aggravated light competition among functional groups, especially between grasses 
and legumes (Hautier et al., 2009; Li et al., 2014a). Legume species are less sensitive to soil $\mathrm{N}$ because they can acquire additional $\mathrm{N}$ by biological $\mathrm{N}_{2}$ fixation in symbiotic association with rhizobia (Song et al., 2012). As such, reduced growth of legumes under intense light competition may lead to their strong local suppression in this study. Such losses in plant richness, in turn, have profound impacts on the productivity and stability of ecosystems (Clark and Tilman, 2008; Isbell et al., 2013).

\subsection{Effects of $N$ and $P$ enrichment on enzyme activities}

$\mathrm{N}$ rather than $\mathrm{P}$ addition stimulated $\beta$-glucosidase activity, while the invertase and acid phosphatase activities were less responsive to $\mathrm{N}$ and/or $\mathrm{P}$ additions (Figs. 3b-d), which was similar to that observed by Tian et al. (2014) in an alpine meadow. The invertase activity in the grassland soil was rather high, and much higher than the 0.3-1.0 and $0.17-0.18 \mathrm{~g} \mathrm{GE} \mathrm{kg}^{-1} \mathrm{~h}^{-1}$ measured in cropland and temperate forest soils, respectively ( $\mathrm{Yu}$ et al., 2012; Li et al., 2014b). Thus, it was likely that high background invertase activity obscured the potential enhancing effect of $\mathrm{N}$ addition.

Interestingly, $\mathrm{N}$ and/or $\mathrm{P}$ additions in the alpine grassland increased chitinase activity (Fig. 3a), which is involved in degrading organic N compounds (Sinsabaugh et al., 2009). This was in contrast to the negative feedback reported by Bragazza et al. (2006) that chitinase activity decreased with increasing $\mathrm{N}$ addition, and by Turner and Wright (2014) that ten-year P fertilization repressed chitinase activity in a lowland tropical rainforest. It is possible that $\mathrm{N}$ amendment in $\mathrm{N}$-limited soil relieved repression on microbial growth, which in turn increased chitinase activity (Chen et al., 
2014; Zhang et al., 2014). Zheng et al. (2015) found that $\mathrm{N}$ addition did not affect acid phosphatase activity in young-growth subtropical forests, and ascribed this to relatively high intrinsic $\mathrm{P}$ availability in the soil. Likewise, relatively high available $\mathrm{P}$ content in the test soil might have resulted in low activity of acid phosphatase, which in turn could reduce the potential suppressive effect of $\mathrm{P}$ addition, and obscured the potential direct stimulation effect of $\mathrm{N}$ addition. Another possible explanation is that part of phosphatase is produced constitutively and is easily stabilized by sorption onto clay surfaces or by interaction with SOC (Olander and Vitousek, 2000; Turner and Wright, 2014), so phosphatase is insensitive to soil $\mathrm{P}$ availability.

\subsection{Effects of $N$ and $P$ enrichment on soil organic $C$}

Previous studies have shown that $\mathrm{N}$ and $\mathrm{P}$ enrichment enhances SOC storage in croplands and forestlands (Bradford et al., 2008; Liu and Greaver, 2010; Lu et al., 2011). Contrary to expectations, the four-year $\mathrm{N}$ and/or $\mathrm{P}$ additions reduced the SOC content in the surface layer in the alpine grassland despite the fact that aboveground plant biomass was considerably increased (Fig. 1 and Table 2). A similar phenomenon has been reported in the Alaskan tundra (Mack et al., 2004). In an alpine meadow, Fang et al. (2014) observed a $4.5 \%$ increase in the SOC stock at a $\mathrm{N}$ addition rate of $10 \mathrm{~kg} \mathrm{~N} \mathrm{ha}^{-1} \mathrm{yr}^{-1}$ but a $5.4-8.8 \%$ decrease at $20-40 \mathrm{~kg} \mathrm{~N} \mathrm{ha}^{-1} \mathrm{yr}^{-1}$ over five years. They suggested that the response of SOC to $\mathrm{N}$ enrichment depended on the $\mathrm{N}$ addition rate, with a threshold level for changing from $\mathrm{C}$ sequestration to $\mathrm{C}$ loss at $\sim 20 \mathrm{~kg} \mathrm{~N}$ $\mathrm{ha}^{-1} \mathrm{yr}^{-1}$. Our results revealed that alpine grassland ecosystems on the 
Qinghai-Tibetan Plateau may become a potential C source under future scenarios of increasing $\mathrm{N}$ and $\mathrm{P}$ enrichment.

Hagedorn et al. (2012) reported that $\mathrm{N}$ fertilization decreased DOC concentration and its aromaticity, and the lignin-derived (so-called hydrophobic) DOC in a mixed beech forest soil. This has been suggested to be due to alleviated $\mathrm{N}$ constraints after $\mathrm{N}$ fertilization on microbes and increased microbial biomass, especially the relative abundance of copiotrophic bacteria (Bragazza et al., 2006; Cusack et al., 2011; Ramirez et al., 2012), which in turn shifts substrates towards labile organic C (Neff et al., 2002; Fierer et al., 2012), resulting in SOC loss. However, this may not be the case in the present study, because no significant discrepancy was found in DOC and EOC contents between the Control and nutrient input treatments (Figs. 2a and b). We found that $\mathrm{N}$ and/or P additions reduced soil ROC content (Fig. 2c), indicating that the decrease of SOC in the alpine grassland ecosystem under $\mathrm{N}$ and $\mathrm{P}$ enrichment was primarily due to decomposition of ROC.

In general, $\mathrm{N}$ addition stimulates the activity of cellulose-degrading enzymes (Carreiro et al., 2000; Saiya-Cork et al., 2002; Keeler et al., 2009). A meta-analysis showed that $\mathrm{N}$ addition promotes the activity of hydrolytic $\mathrm{C}$-acquiring enzymes by 9.1\%, and a high $\mathrm{N}$ addition rate exhibits a stronger effect (Jian et al., 2016; Chen et al., 2017). In this study, the cellulase activity was also stimulated by $\mathrm{N}$ addition (Fig. 3e), which is involved in the decomposition of cellulose, a constituent of recalcitrant C (Keeler et al., 2009; Du et al., 2014). The cellulase activity further showed negative correlations with the size of the soil slow $\mathrm{C}$ pool and ROC content (Fig. 5a and Table 
4), which may explain the increased mineralization of the recalcitrant $\mathrm{C}$ after $\mathrm{N}$ addition. $\mathrm{N}$ addition simultaneously increased polyphenol oxidase activity (Fig. 3f), which is responsible for the decomposition of recalcitrant polymers such as lignin and humic acids (Sinsabaugh, 2010), and there was a negative relationship between polyphenol oxidase activity and the size of soil slow C pool or SOC content (Fig. 5b and Table 4). Waldrop et al. (2004) also measured a stimulation effect of $\mathrm{N}$ addition on polyphenol oxidase activity in a sugar maple-dominant ecosystem with low lignin in litter.

In contrast, other studies revealed that the activities of lignin-degrading enzymes often decrease under $\mathrm{N}$ enrichment in forests (Zak et al., 2008; Hobbie et al., 2012), probably due to reduced abundance of fungi, especially white rot fungi (Carreiro et al., 2000), actinobacteria (Eisenlord et al., 2013), and even bacteria (Saiya-Cork et al., 2002). Interestingly, in this study, the activity of chitinase, an enzyme closely related to fungal growth and activity, was also increased by $\mathrm{N}$ addition, and was positively correlated with cumulative SOC mineralization (Fig. 4a), as reported by Allison et al. (2009) in boreal forest. It was suggested that the different responses of polyphenol oxidase activity to $\mathrm{N}$ addition arise from site-specific differences in the fungal community. Ascomycota were found to be more tolerant of high $\mathrm{N}$ relative to the Basidiomycota (Nemergut et al., 2008), and $\mathrm{N}$ amendment stimulated the growth of the dominant fungi Ascomycota but not Basidomycota in a grassland, which had less lignin content in the plant tissue than forest (Sinsabaugh, 2010; Leff et al., 2015). More improtantly, Xu et al. (2017b) suggested that the activity of microbes, especially 
fungi, was primarily dependent on the availability of energy resources, especially labile organic $\mathrm{C}$, and that deficiency or quality decrease of DOC at the later stage of litter decompostion retarded the fungi growth following $\mathrm{N}$ addition in a forest soil. In grasslands, Eisenhauer et al. (2012) attributed reduction of microbial activity to less root growth and exudates. In general, up to $50 \%$ of photosynthetic $\mathrm{C}$ is delivered to the underground (Liu and Greaver, 2010). In the present study, it was likely that the increased aboveground plant biomass under $\mathrm{N}$ addition transferred more labile organic C, such as litters and exudates, into the soil (Bradford et al., 2008; Treseder, 2008), which in turn maintained and even increased the microbial biomass, especially the abundance of fungi, leading to an increase in the activities of chitinase and polyphenol oxidase (Cusack et al., 2011; Eisenhauer et al., 2012). An increased abundance of fungi due to $\mathrm{N}$ addition produces more hyphae, which in turn more efficiently penetrate into soil organic matter and increase the degradation of recalcitrant C (Sinsabaugh, 2010; Strickland and Rousk, 2010). In this way, part of the $\mathrm{C}$ in the slow $\mathrm{C}$ pool was transferred into the active $\mathrm{C}$ pool in the $\mathrm{N}$ amendment treatments (Table 3; Du et al., 2014).

A meta-analysis of $95{ }^{14} \mathrm{C}$-labeled plant studies showed that $5-10 \%$ of photosynthetically fixed C was recovered in soil (Farrar et al., 2003). In the test alpine grassland, however, increased aboveground plant biomass as litters and exudates under $\mathrm{N}$ enrichment failed to replenish SOC loss. First, previous studies have pointed out that increased soil-available $\mathrm{N}$ may reduce root biomass and exudates in the soil by $25 \%$ (Janssens et al., 2010; Chen et al., 2015). Second, increased input of plant 
litters in the $\mathrm{N}$-added plots was more easily decomposed than in the Control plots in the alpine grassland (Knorr et al., 2005). The decomposition rate of plant residues is strongly associated with the ratio of S (syringyl) to $\mathrm{G}$ (guaiacyl) in lignin (Xu et al., 2017a). This is because the syringyl units are formed with labile $\beta-O-4$ linkages that can be degraded quickly, and the guaiacyl units can polymerize to generate recalcitrant condensed aryl-aryl linkages (Bahri et al., 2006; Talbot et al., 2012). Enhanced $\mathrm{N}$ availability lowered the $\mathrm{C}: \mathrm{N}$ ratio of plant tissues in an alpine meadow due to an increase in grasses, which had higher $\mathrm{N}$ utilization efficiency than other species (Li et al., 2014a), and improved litter quality and increased decomposition rates above soil, thereby resulting in less litter C into SOC (Knorr et al., 2005; Hobbie et al., 2012). For example, soybean residues with high $\mathrm{N}$ concentration and $\mathrm{S} / \mathrm{G}$ ratio exhibited a higher decomposition rate compared with wheat residues $(\mathrm{Xu}$ et al., 2017a). Third, Yuan and Chen (2012) suggested that $\mathrm{N}$ addition increases the production of fine root, which is poor in lignin and suberin. Therefore, $\mathrm{N}$ probably increased the percentage of fine root biomass, and drove the distribution of root biomass towards the soil surface (Mack et al., 2004), leading to more rapid decomposition of roots in the fertilized plots. In this study, we did not measure the quality and decomposition of plant litters and roots, and further studies are required to evaluate the contribution of plants to SOC.

Compared with $\mathrm{N}$, the effects of $\mathrm{P}$ enrichment on soil $\mathrm{C}$ cycling have rarely been addressed. Keuskamp et al. (2015) observed that $\mathrm{P}$ amendment suppressed polyphenol oxidase activity in mangrove peat, as more tannis amd other polyphenolic compounds 
inhibited microbes from producing extracellular enzymes. In the present study, P addition efficiently increased polyphenol oxidase activity (Fig. 3f). Previous studies found that application of $\mathrm{P}$ increased microbial biomass and altered the microbial community composition by enhancing fungi to bacteria ratio in forest soils (Liu et al., 2012; Li et al., 2015). Thus, it is likely that the increased abundance of fungi was responsible for the enhanced polyphenol oxidase activity in the present study; in turn, the increased activity of polyphenol oxidase might have stimulated lignin decomposition and supplied more cellulose substrate for cellulase under P addition, leading to an increase in cellulase activity (Fig. 3e). As with $\mathrm{N}$ addition, enhanced cellulase and polyphenol oxidase activity increases organic $\mathrm{C}$ decomposition in soil (Waldrop et al., 2004; Knorr et al., 2005). It has recently been shown that $\mathrm{P}$ amendment can promote heterotrophic respiration not only in P-limited tropical forests (Cleveland and Townsend, 2006; Nottingham et al., 2015) but also in northern hardwood forests (Fisk et al., 2015), suggesting that the promoting effect of $\mathrm{P}$ addition on heterotrophic respiration is not restricted to P-limited soils. These results underline that $\mathrm{P}$ amendment does indeed promote microbial growth and activity. Poeplau et al. (2016) found a decrease in SOC stocks after long-term P fertilization despite the fact that more crop residues entered into soil in Swedish agricultural field experiments. Slightly differently, Fornara et al. (2013) reported that although P addition increased abovegound plant biomass, soil $\mathrm{C}$ sequestration was not influenced. Thus, the influence of $\mathrm{P}$ amendment on SOC content probably depends on the balance between the promoting effect of $\mathrm{P}$ on plant-derived $\mathrm{C}$ input and $\mathrm{C}$ loss by microbial activity in 
soil. Fisk et al. (2015) proposed that high P availability stimulated respiratory losses of added leaf litter by alleviating $\mathrm{P}$ limitation on microbial metabolism. In general, $\mathrm{P}$ deficiency limits microbial metabolism, as rates of protein synthesis are restricted by the high $\mathrm{P}$ demands of ribosomes (Hartman and Richardson, 2013). Our results support the conclusion by Hartman and Richardson (2013) that $\mathrm{qCO}_{2}$ increases following the addition of inorganic $\mathrm{P}$ (Table 1). Thus, $\mathrm{P}$ enrichment caused less efficient microbial utilization of $\mathrm{C}$ as indicated by higher $\mathrm{qCO}_{2}$, thereby resulting in great $\mathrm{C}$ losses through respiration in this study (Thirukkumaran and Parkinson, 2000; Manzoni et al., 2012). Our results highlight that understanding the interaction between $\mathrm{P}$ availability and soil $\mathrm{C}$ dynamics is of paramount importance for linking $\mathrm{P}$ cycling with C turnover in alpine grasslands (Reed et al., 2015), especially under future senarios of increasing $\mathrm{N}$ addition.

\section{Conclusions}

Our four-year nutrient enrichment experiment in an alpine grassland of the Qinghai-Tibetan Plateau revealed that $\mathrm{N}$ addition increased aboveground plant biomass and decreased species richness mainly due to the increase in the dominant grasses species. In contrast, $\mathrm{N}$ and/or $\mathrm{P}$ additions decreased SOC content in the surface layer $(0-10 \mathrm{~cm})$ by increasing recalcitrant organic $\mathrm{C}$ decomposition, but not in the $20-40 \mathrm{~cm}$ layer. The decrease in SOC in response to nutrient enrichment is uncommon in grassland ecosystems and was attributable to increases in activities of enzymes responsible for various steps of SOC decomposition. Microbial biomass and 
activities of C-degrading enzymes ( $\beta$-glucosidase, cellulase and polyphenol oxidase) and an N-degrading enzyme (chitinase) increased following nutrient addition. The activities of cellulase and chitinase were positively correlated with $\mathrm{CO}_{2}$ emissions, and the soil slow $\mathrm{C}$ pool had a negative correlation with cellulase and polyphenol oxidase activities. Our results suggest that the increase in anthropogenic $\mathrm{N}$ and $\mathrm{P}$ input alleviated the nutrient limitation in soils on the Tibetan Plateau and may shift the alpine grassland from a $\mathrm{C}$ sink to a potential $\mathrm{C}$ source.

\section{Acknowledgements}

We would like to thank the staff at Haibei Alpine Grassland Ecosystem Research Station, Chinese Academy of Sciences for their great logistic support and helpful assistance in the field experiment. This work was supported by the National Program on Key Basic Research Project (2014CB954002), the Strategic Priority Research Program of the Chinese Academy of Sciences (XDB15020100), the National Natural Science Foundation of China $(31561143011,41271243)$ and the "RUDN University Program 5-100”. We thank Soil Science Consulting (https://soilscicon.wordpress.com) for help by the paper preparation.

\section{References}

Allison, S.D., Czimczik, C.I., Treseder, K.K., 2008. Microbial activity and soil respiration under nitrogen addition in Alaskan boreal forest. Glob. Chang. Biol. $14,1156-1168$. 
Allison, S.D., LeBauer, D.S., Ofrecio, M.R., Reyes, R., Ta, A.-M., Tran, T.M., 2009. Low levels of nitrogen addition stimulate decomposition by boreal forest fungi. Soil Biol. Biochem. 41, 293-302.

Bahri, H., Dignac, M., Rumpel, C., Rasse, D.P., Chenu, C., Mariotti, A., 2006. Lignin turnover kinetics in an agricultural soil is monomer specific. Soil Biol. Biochem. 38, 1977-1988.

Bobbink, R., Hicks, K., Galloway, J., Spranger, T., Alkemade, R., Ashmore, M., Bustamante, M., Cinderby, S., Davidson, E., Dentener, F., Emmett, B., Erisman, J.-W., Fenn, M., Gilliam, F., Nordin, A., Pardo, L., de Vries, W.I.M., 2010. Global assessment of nitrogen deposition effects on terrestrial plant diversity: a synthesis. Ecol. Appl. 20, 30-59.

Bradford, M.A., Fierer, N., Jackson, R.B., Maddox, T.R., Reynolds, J.F., 2008. Nonlinear root-derived carbon sequestration across a gradient of nitrogen and phosphorous deposition in experimental mesocosms. Glob. Chang. Biol. 14, $1113-1124$.

Bragazza, L., Freeman, C., Jones, T., Rydin, H., Limpens, J., Fenner, N., Ellis, T., Gerdol, R., Hajek, M., Hajek, T., Iacumin, P., Kutnar, L., Tahvanainen, T., Toberman, H., 2006. Atmospheric nitrogen deposition promotes carbon loss from peat bogs. Proc. Natl. Acad. Sci. U. S. A. 103, 10316-10321.

Burns, R.G., DeForest, J.L., Marxsen, J., Sinsabaugh, R.L., Stromberger, M.E., Wallenstein, M.D., Weintraub, M.N., Zoppini, A., 2013. Soil enzymes in a changing environment: Current knowledge and future directions. Soil Biol. 
Biochem. 58, 216-234.

Carreiro, M.M., Sinsabaugh, R.L., Repert, D.A., Parkhurst, D.F., 2000. Microbial enzyme shifts explain litter decay responses to simulated nitrogen deposition. Ecology 81, 2359-2365.

Carter, M.R., 1993. Soil Sampling and Methods of Analysis. Lewis Publishers, Boca Raton, FL.

Chen, H., Zhu, Q.A., Peng, C.H., Wu, N., Wang, Y.F., Fang, X.Q., Gao, Y.H., Zhu, D., Yang, G., Tian, J.Q., Kang, X.M., Piao, S.L., Ouyang, H., Xiang, W.H., Luo, Z.B., Jiang, H., Song, X.Z., Zhang, Y., Yu, G.R., Zhao, X.Q., Gong, P., Yao, T.D., Wu, J.H., 2013. The impacts of climate change and human activities on biogeochemical cycles on the Qinghai-Tibetan Plateau. Glob. Chang. Biol. 19, $2940-2955$.

Chen, R.R., Senbayram, M., Blagodatsky, S., Myachina, O., Dittert, K., Lin, X.G., Blagodatskaya, E., Kuzyakov, Y., 2014. Soil C and N availability determine the priming effect: microbial $\mathrm{N}$ mining and stoichiometric decomposition theories. Glob. Chang. Biol. 20, 2356-2367.

Chen, H., Li, D.J., Gurmesa, G.A., Yu, G.R., Li, L.H., Zhang, W., Fang, H.J., Mo, J.M., 2015. Effects of nitrogen deposition on carbon cycle in terrestrial ecosystems of China: A meta-analysis. Environ. Pollut. 206, 352-360.

Chen, J., Luo, Y.Q., Li, J.W., Zhou, X.H., Cao, J.J., Wang, R.-W., Wang, Y.Q., Shelton, S., Jin, Z., Walker, L.M., Feng, Z.Z., Niu, S.L., Feng, W.T., Jian, S.Y., Zhou, L.Y., 2017. Costimulation of soil glycosidase activity and soil respiration by nitrogen 
addition. Glob. Chang. Biol. 23, 1328-1337.

Clark, C.M., Tilman, D., 2008. Loss of plant species after chronic low-level nitrogen deposition to prairie grasslands. Nature $451,712-715$.

Cleveland, C.C., Townsend, A.R., 2006. Nutrient additions to a tropical rain forest drive substantial soil carbon dioxide losses to the atmosphere. Proc. Natl. Acad. Sci. U. S. A. 103, 10316-10321.

Cusack, D.F., Silver, W.L., Torn, M.S., Burton, S.D., Firestone, M.K., 2011. Changes in microbial community characteristics and soil organic matter with nitrogen additions in two tropical forests. Ecology 92, 621-632.

Davidson, E.A., Janssens, I.A., 2006. Temperature sensitivity of soil carbon decomposition and feedbacks to climate change. Nature 440, 165-173.

Du, Y.H., Guo, P., Liu, J.Q., Wang, C.Y., Yang, N., Jiao, Z.X., 2014. Different types of nitrogen deposition show variable effects on the soil carbon cycle process of temperate forests. Glob. Chang. Biol. 20, 3222-3228.

Eisenhauer, N., Cesarz, S., Koller, R., Worm, K., Reich, P.B., 2012. Global change belowground: impacts of elevated $\mathrm{CO}_{2}$, nitrogen, and summer drought on soil food webs and biodiversity. Glob. Chang. Biol. 18, 435-447.

Eisenlord, S.D., Freedman, Z., Zak, D.R., Xue, K., He, Z.L., Zhou, J.Z., 2013. Microbial mechanisms mediating increased soil $\mathrm{C}$ storage under elevated atmospheric N deposition. Appl. Environ. Microbiol. 79, 1191-1199.

Elser, J.J., Bracken, M.E., Cleland, E.E., Gruner, D.S., Harpole, W.S., Hillebrand, H., Ngai, J.T., Seabloom, E.W., Shurin, J.B., Smith, J.E., 2007. Global analysis of 
nitrogen and phosphorus limitation of primary producers in freshwater, marine and terrestrial ecosystems. Ecol. Lett. 10, 1135-1142.

Fang, H.J., Cheng, S.L., Yu, G.R., Yang, X.M., Xu, M.J., Wang, Y.S., Li, L.S., Dang, X.S., Wang, L., Li, Y.N., 2014. Nitrogen deposition impacts on the amount and stability of soil organic matter in an alpine meadow ecosystem depend on the form and rate of applied nitrogen. Eur. J. Soil Sci. 65, 510-519.

Farrar, J., Hawes, M., Jones, D., Lindow, S., 2003. How roots control the flux of carbon to the rhizosphere. Ecology 84, 827-837.

Fierer, N., Lauber, C.L., Ramirez, K.S., Zaneveld, J., Bradford, M.A., Knight, R., 2012. Comparative metagenomic, phylogenetic and physiological analyses of soil microbial communities across nitrogen gradients. ISME J. 6, 1007-1017.

Fisk, M., Santangelo, S., Minick, K., 2015. Carbon mineralization is promoted by phosphorus and reduced by nitrogen addition in the organic horizon of northern hardwood forests. Soil Biol. Biochem. 81, 212-218.

Fornara, D.A., Banin, L., Crawley, M.J., 2013. Multi-nutrient vs. nitrogen-only effects on carbon sequestration in grassland soils. Glob. Chang. Biol. 19, 3848-3857.

Frey, S.D., Ollinger, S., Nadelhoffer, K., Bowden, R., Brzostek, E., Burton, A., Caldwell, B.A., Crow, S., Goodale, C.L., Grandy, A.S., Finzi, A., Kramer, M.G., Lajtha, K., LeMoine, J., Martin, M., McDowell, W.H., Minocha, R., Sadowsky, J.J., Templer, P.H., Wickings, K., 2014. Chronic nitrogen additions suppress decomposition and sequester soil carbon in temperate forests. Biogeochemistry $121,305-316$. 
Galloway, J.N., Townsend, A.R., Erisman, J.W., Bekunda, M., Cai, Z.C., Freney, J.R., Martinelli, L.A., Seitzinger, S.P., Sutton, M.A., 2008. Transformation of the nitrogen cycle: recent trends, questions, and potential solutions. Science 320, 889-892.

Guan, S.Y., Zhang, D., Zhang, Z., 1986. Soil Enzyme and Its Research Methods. Agriculture Press, Beijing (in Chinese).

Hagedorn, F., Kammer, A., Schmidt, M.W.I., Goodale, C.L., 2012. Nitrogen addition alters mineralization dynamics of ${ }^{13} \mathrm{C}$-depleted leaf and twig litter and reduces leaching of older DOC from mineral soil. Glob. Chang. Biol. 18, 1412-1427.

Harpole, W.S., Ngai, J.T., Cleland, E.E., Seabloom, E.W., Borer, E.T., Bracken, M.E., Elser, J.J., Gruner, D.S., Hillebrand, H., Shurin, J.B., Smith, J.E., 2011. Nutrient co-limitation of primary producer communities. Ecol. Lett. 14, 852-862.

Hartman, W.H., Richardson, C.J., 2013. Differential nutrient limitation of soil microbial biomass and metabolic quotients $\left(\mathrm{qCO}_{2}\right)$ : is there a biological stoichiometry of soil microbes? PLoS One 8, e57127.

Hautier, Y., Niklaus, P.A., Hector, A., 2009. Competition for light causes plant biodiversity loss after eutrophication. Science 324, 636-638.

van der Heijden, M.G., Bardgett, R.D., van Straalen, N.M., 2008. The unseen majority: soil microbes as drivers of plant diversity and productivity in terrestrial ecosystems. Ecol. Lett. 11, 296-310.

Hobbie, S.E., Eddy, W.C., Buyarski, C.R., Carol-Adair, E., Ogdahl, M.L., Weisenhorn, P., 2012. Response of decomposing litter and its microbial community to 
multiple forms of nitrogen enrichment. Ecol. Monogr. 82, 389-405.

Isbell, F., Reich, P.B., Tilman, D., Hobbie, S.E., Polasky, S., Binder, S., 2013. Nutrient enrichment, biodiversity loss, and consequent declines in ecosystem productivity. Proc. Natl. Acad. Sci. U. S. A. 110, 11911-11916.

Janssens, I.A., Dieleman, W., Luyssaert, S., Subke, J.A., Reichstein, M., Ceulemans, R., Ciais, P., Dolman, A.J., Grace, J., Matteucci, G., Papale, D., Piao, S.L., Schulze, E.D., Tang, J., Law, B.E., 2010. Reduction of forest soil respiration in response to nitrogen deposition. Nat. Geosci. 3, 315-322.

Jian, S.Y., Li, J.W., Chen, J., Wang, G.S., Mayes, M.A., Dzantor, K.E., Hui, D.F., Luo, Y.Q., 2016. Soil extracellular enzyme activities, soil carbon and nitrogen storage under nitrogen fertilization: A meta-analysis. Soil Biol. Biochem. 101, 32-43.

Keeler, B.L., Hobbie, S.E., Kellogg, L.E., 2009. Effects of long-term nitrogen addition on microbial enzyme activity in eight forested and grassland sites: implications for litter and soil organic matter decomposition. Ecosystems 12, $1-15$.

Keuskamp, J.A., Feller, I.C., Laanbroek, H.J., Verhoeven, J.T.A., Hefting, M.M., 2015. Short- and long-term effects of nutrient enrichment on microbial exoenzyme activity in mangrove peat. Soil Biol. Biochem. 81, 38-47.

Knorr, M., Frey, S.D., Curtis, P.S., 2005. Nitrogen additions and litter decomposition: A meta-analysis. Ecology 86, 3252-3257.

Lebauer, D.S., Treseder, K.K., 2008. Nitrogen limitation of net primary productivity in terrestrial ecosystems is globally distributed. Ecology 89, 371-379. 
Leff, J.W., Jones, S.E., Prober, S.M., Barberan, A., Borer, E.T., Firn, J.L., Harpole, W.S., Hobbie, S.E., Hofmockel, K.S., Knops, J.M., McCulley, R.L., La Pierre, K., Risch, A.C., Seabloom, E.W., Schutz, M., Steenbock, C., Stevens, C.J., Fierer, N., 2015. Consistent responses of soil microbial communities to elevated nutrient inputs in grasslands across the globe. Proc. Natl. Acad. Sci. U. S. A. 112, 10967-10972.

Li, J.H., Yang, Y.J., Li, B.W., Li, W.J., Wang, G., Knops, J.M., 2014a. Effects of nitrogen and phosphorus fertilization on soil carbon fractions in alpine meadows on the Qinghai-Tibetan Plateau. PLoS One 9, e103266.

Li, S.S., Du, Y.H., Guo, P., Guo, L.D., Qu, K.Y., He, J.P., 2014b. Effects of different types of $\mathrm{N}$ deposition on the fungal decomposition activities of temperate forest soils. Sci. Total Environ. 497-498, 91-96.

Li, J., Li, Z.A., Wang, F. M., Zou, B., Chen, Y., Zhao, J., Mo, Q.F., Li, Y.W., Li, X.B., Xia, H.P., 2015. Effects of nitrogen and phosphorus addition on soil microbial community in a secondary tropical forest of China. Biol. Fertil. Soils 51, $207-215$.

Li, Y., Niu, S.L., Yu, G.R., 2016. Aggravated phosphorus limitation on biomass production under increasing nitrogen loading: a meta-analysis. Glob. Chang. Biol. $22,934-943$.

Limpens, J., Berendse, F., Klees, H., 2003. $\mathrm{N}$ depoistion affect $\mathrm{N}$ availability in interstitial water, growth of Sphagnum and invasion of vascular platns in bog vegetation. New Phytol. 157, 339-347. 
Liu, L.L., Greaver, T.L., 2010. A global perspective on belowground carbon dynamics under nitrogen enrichment. Ecol. Lett. 13, 819-828.

Liu, L., Gundersen, P., Zhang, T., Mo, J.M., 2012. Effects of phosphorus addition on soil microbial biomass and community composition in three forest types in tropical China. Soil Biol. Biochem. 44, 31-38.

Liu, X.J., Zhang, Y., Han, W.X., Tang, A.H., Shen, J.L., Cui, Z.L., Vitousek, P., Erisman, J.W., Goulding, K., Christie, P., Fangmeier, A., Zhang, F.S., 2013. Enhanced nitrogen deposition over China. Nature 494, 459-462.

Liu, S., Zamanian, K., Schleuss, P., Zarebanadkouki, M., Kuzyakov, Y., 2018. Degradation of Tibetan grasslands: Consequences for carbon and nutrient cycles. Agric. Ecosyst. Environ. 252, 93-104.

Lu, M., Zhou, X.H., Luo, Y.Q., Yang, Y.H., Fang, C.M., Chen, J.K., Li, B., 2011. Minor stimulation of soil carbon storage by nitrogen addition: A meta-analysis. Agric. Ecosyst. Environ. 140, 234-244.

Maaroufi, N.I., Nordin, A., Hasselquist, N.J., Bach, L.H., Palmqvist, K., Gundale, M.J., 2015. Anthropogenic nitrogen deposition enhances carbon sequestration in boreal soils. Glob. Chang. Biol. 21, 3169-3180.

Mack, M.C., Schuur, E.A.G., Bret-Harte, M.S., Shaver, G.R., Chapin F.S., III., 2004. Ecosystem carbon storage in arctic tundra reduced by long-term nutrient fertilization. Nature 431, 440-443.

Mahowald, N., Jickells, T.D., Baker, A.R., Artaxo, P., Benitez-Nelson, C.R., Bergametti, G., Bond, T.C., Chen, Y., Cohen, D.D., Herut, B., Kubilay, N., Losno, 
R., Luo, C., Maenhaut, W., McGee, K.A., Okin, G.S., Siefert, R.L., Tsukuda, S., 2008. Global distribution of atmospheric phosphorus sources, concentrations and deposition rates, and anthropogenic impacts. Glob. Biogeochem. Cycles 22, GB4026.

Manzoni, S., Taylor, P., Richter, A., Porporato, A., Ågren, G.I., 2012. Environmental and stoichiometric controls on microbial carbon-use efficiency in soils. New Phytol. 196, 79-91.

Mirsky, S.B., Lanyon, L.E., Needelman, B.A., 2008. Evaluating soil management using particulate and chemically labile soil organic matter fractions. Soil Sci. Soc. Am. J. 72, 180-185.

Murphy, J., Riley, J.P., 1962. A modified single solution method for the determination of phosphate in natural waters. Anal. Chim. Acta 27, 31-36.

Neff, J.C., Townsend, A.R., Gleixnerk, G., Lehman, S.J., Turnbull, J., Bowman, W.D., 2002. Variable effects of nitrogen additions on the stability and turnover of soil carbon. Nature 419, 915-917.

Nemergut, D.R., Townsend, A.R., Sattin, S.R., Freeman, K.R., Fierer, N., Neff, J.C., Bowman, W.D., Schadt, C.W., Weintraub, M.N., Schmidt, S.K., 2008. The effects of chronic nitrogen fertilization on alpine tundra soil microbial communities: implications for carbon and nitrogen cycling. Environ. Microbiol. $10,3093-3105$.

Nottingham, A.T., Turner, B.L., Stott, A.W., Tanner, E.V.J., 2015. Nitrogen and phosphorus constrain labile and stable carbon turnover in lowland tropical forest 
soils. Soil Biol. Biochem. 80, 26-33.

Ochoa-Hueso, R., Maestre, F.T., de Los Rios, A., Valea, S., Theobald, M.R., Vivanco, M.G., Manrique, E., Bowker, M.A., 2013. Nitrogen deposition alters nitrogen cycling and reduces soil carbon content in low-productivity semiarid Mediterranean ecosystems. Environ. Pollut. 179, 185-193.

Olander, L.P., Vitousek, P.M., 2000. Regulation of soil phosphatase and chitinase activity by $\mathrm{N}$ and $\mathrm{P}$ availability. Biogeochemistry 49, 175-190.

Paul, E.A., Morris, S.J., Conant, R.T., Plante, A.F., 2006. Does the acid hydrolysis-incubation method measure meaningful soil organic carbon pools? Soil Sci. Soc. Am. J. 70, 1023-1035.

Peñuelas, J., Poulter, B., Sardans, J., Ciais, P., van der Velde, M., Bopp, L., Boucher, O., Godderis, Y., Hinsinger, P., Llusia, J., Nardin, E., Vicca, S., Obersteiner, M., Janssens, I.A., 2013. Human-induced nitrogen-phosphorus imbalances alter natural and managed ecosystems across the globe. Nat. Commun. 4, 2934.

Poeplau, C., Bolinder, M.A., Kirchmann, H., Kätterer, T., 2016. Phosphorus fertilisation under nitrogen limitation can deplete soil carbon stocks: evidence from Swedish meta-replicated long-term field experiments. Biogeosciences 13, $1119-1127$.

Qiu, J., 2008. China: the third pole. Nature 454, 393-396.

Ramirez, K.S., Craine, J.M., Fierer, N., 2012. Consistent effects of nitrogen amendments on soil microbial communities and processes across biomes. Glob. Chang. Biol. 18, 1918-1927. 
Reed, S.C., Yang, X.J., Thornton, P.E., 2015. Incorporating phosphorus cycling into global modeling efforts: a worthwhile, tractable endeavor. New Phytol. 208, $324-329$

Rodriguez-Kabana, G., Godoy, G., Morgan-Jones, G., Shelby, R.A., 1983. The determination of soil chitinase activity: Conditions for assay and ecological studies. Plant Soil 75, 95-106.

Saiya-Cork, K.R., Sinsabaugh, R.L., Zak, D.R., 2002. The effects of long term nitrogen deposition on extracellular enzyme activity in an Acer saccharum forest soil. Soil Biol. Biochem. 32, 1309-1315.

Schinner, F., von Mersi, W., 1990. Xylanase-, CM-cellulase- and invertase activity in soil: an improved method. Soil Biol. Biochem. 22, 511-515.

Schmidt, M.W., Torn, M.S., Abiven, S., Dittmar, T., Guggenberger, G., Janssens, I.A., Kleber, M., Kogel-Knabner, I., Lehmann, J., Manning, D.A., Nannipieri, P., Rasse, D.P., Weiner, S., Trumbore, S.E., 2011. Persistence of soil organic matter as an ecosystem property. Nature $478,49-56$.

Sinsabaugh, R.L., Hill, B.H., Shah, J.J.F., 2009. Ecoenzymatic stoichiometry of microbial organic nutrient acquisition in soil and sediment. Nature 462, 795-798.

Sinsabaugh, R. L., 2010. Phenol oxidase, peroxidase and organic matter dynamics of soil. Soil Biol. Biochem. 42, 391-404.

Song, M.H., Yu, F.H., Ouyang, H., Cao, G.M., Xu, X.L., Cornelissen, J.H.C., 2012. Different inter-annual responses to availability and form of nitrogen explain species coexistence in an alpine meadow community after release from grazing. 
Glob. Chang. Biol. 18, 3100-3111.

Strickland, M.S., Rousk, J., 2010. Considering fungal:bacterial dominance in soils Methods, controls, and ecosystem implications. Soil Biol. Biochem. 42, $1385-1395$.

Tabatabai, M.A., 1994. Soil enzymes. In: Weaver, R.W., Angle, J.S., Bottomley, P.S. (Eds.), Methods of Soil Analysis, Part 2-Microbiological and Biochemical Properties. Soil Science Society of America, Madison, pp. 775-833.

Talbot, J.M., Yelle, D.J., Nowick, J., Treseder, K.K., 2012. Litter decay rates are determined by lignin chemistry. Biogeochemistry 108, 279-295.

Thirukkumaran, C.M., Parkinson, D., 2000. Microbial respiration, biomass, metabolic quotient and litter decomposition in a lodgepole pine forest floor amended with nitrogen and phosphorous fertilizers. Soil Biol. Biochem. 32, 59-66.

Tian, X.F., Hu, H.W., Ding, Q., Song, M.H., Xu, X.L., Zheng, Y., Guo, L.D., 2014. Influence of nitrogen fertilization on soil ammonia oxidizer and denitrifier abundance, microbial biomass, and enzyme activities in an alpine meadow. Biol. Fertil. Soils 50, 703-713.

Treseder, K.K., 2008. Nitrogen additions and microbial biomass: a meta-analysis of ecosystem studies. Ecol. Lett. 11, 1111-1120.

Trumbore, S.E., Czimczik, C.I., 2008. An uncertain future for soil carbon. Nature 321, $1455-1456$.

Turner, B.L., Wright, S.J., 2014. The response of microbial biomass and hydrolytic enzymes to a decade of nitrogen, phosphorus, and potassium addition in a 
lowland tropical rain forest. Biogeochemistry 117, 115-130.

Vance, E.D., Brookes, P.C., Jenkinson, D.S., 1987. An extraction method for measuring soil microbial biomass C. Soil Biol. Biochem. 19, 703-707.

Waldrop, M.P., Zak, D.R., Sinsabaugh, R.L., Gallo, M., Lauber, C., 2004. Nitrogen deposition modifies soil carbon storage through changes in microbial enzymatic activity. Ecol. Appl. 14, 1172-1177.

Wang, G.X., Qian, J., Cheng, G.D., Lai, Y.M., 2002. Soil organic carbon pool of grassland soils on the Qinghai-Tibetan. Sci. Total Environ. 291, 207-217.

Wang, S.P., Duan, J.C., Xu, G.P., Wang, Y.F., Zhang, Z.H., Rui, Y.C., Luo, C.Y., Xu, B., Zhu, X.X., Chang, X.F., Cui, X.Y., Niu, H.S., Zhao, X.Q., Wang, W.Y., 2012. Effects of warming and grazing on soil $\mathrm{N}$ availability, species composition, and ANPP in an alpine meadow. Ecology 93, 2365-2376.

Wang, R., Balkanski, Y., Boucher, O., Ciais, P., Peñuelas, J., Tao, S., 2015. Significant contribution of combustion-related emissions to the atmospheric phosphorus budget. Nat. Geosci. 8, 48-54.

Xu, X.L., Ouyang, H., Cao, G.M., Richter, A., Wanek, W., Kuzyakov, Y., 2011. Dominant plant species shift their nitrogen uptake patterns in response to nutrient enrichment caused by a fungal fairy in an alpine meadow. Plant Soil 341, $495-504$

Xu, Y.H., Chen, Z.M., Fontaine, S., Wang, W.J., Luo, J.F., Fan, J.L., Ding, W.X., 2017a. Dominant effects of organic carbon chemistry on decomposition dynamics of crop residues in a Mollisol. Soil Biol. Biochem. 115, 221-232. 
Xu, Y.H., Fan, J.L., Ding, W.X., Gunina, A., Chen, Z.M., Bol, R., Luo, J.F., Bolan, N., 2017b. Characterization of organic carbon in decomposing litter exposed to nitrogen and sulfur additions: Links to microbial community composition and activity. Geoderma 286, 116-124.

Yang, Y.H., Fang, J.Y., Tang, Y.H., Ji, C.J., Zheng, C.Y., He, J.S., Zhu, B., 2008. Storage, patterns and controls of soil organic carbon in the Tibetan grasslands. Glob. Chang. Biol. 14, 1592-1599.

Yu, H.Y., Ding, W.X., Luo, J.F., Geng, R.L., Ghani, A., Cai, Z.C., 2012. Effects of long-term compost and fertilizer application on stability of aggregate-associated organic carbon in an intensively cultivated sandy loam soil. Biol. Fertil. Soils 48, $325-336$.

Yuan, Z.Y., Chen, H.Y., 2012. A global analysis of fine root production as affected by soil nitrogen and phosphorus. Proc. R. Soc. B Biol. Sci. 279, 3796-3802.

Zak, D.R., Holmes, W.E., Burton, A.J., Pregitzer, K.S., Talhelm, A.F., 2008. Simulated atmospheric $\mathrm{NO}_{3}{ }^{-}$deposition increases soil organic matter by slowing decomposition. Ecol. Appl. 18, 2016-2027.

Zhang, C.P., Niu, D.C., Hall, S.J., Wen, H.Y., Li, X.D., Fu, H., Wan, C.G., Elser, J.J., 2014. Effects of simulated nitrogen deposition on soil respiration components and their temperature sensitivities in a semiarid grassland. Soil Biol. Biochem. $75,113-123$.

Zheng, M.H., Huang, J., Chen, H., Wang, H., Mo, J.M., 2015. Responses of soil acid phosphatase and beta-glucosidase to nitrogen and phosphorus addition in two 
subtropical forests in southern China. Eur. J. Soil Sci. 68, 77-84.

Zhu, J.X., Wang, Q.F., He, N.P., Smith, M.D., Elser, J.J., Du, J.Q., Yuan, G.F., Yu, G.R., Yu, Q., 2016. Imbalanced atmospheric nitrogen and phosphorus depositions in China: Implications for nutrient limitation. J. Geophys. Res. Biogeosci. 121, $1605-1616$. 


\section{Figure legends}

Fig. 1. Effects of $\mathrm{N}$ and $\mathrm{P}$ enrichment on soil organic carbon content in three soil layers. Vertical bars denote the standard errors of the means $(n=4)$. Different letters indicate significant differences among treatments at $P<0.05$.

Fig. 2. Effects of $\mathrm{N}$ and $\mathrm{P}$ enrichment on dissolved organic carbon (DOC), easily oxidizable carbon (EOC), recalcitrant organic carbon (ROC), and microbial biomass carbon $(\mathrm{MBC})$ contents in the surface layer $(0-10 \mathrm{~cm})$. Vertical bars denote the standard errors of the means $(n=4)$. Different letters indicate significant differences among treatments at $P<0.05$.

Fig. 3. Effects of $\mathrm{N}$ and $\mathrm{P}$ enrichment on activities of chitinase (a), acid phosphatase (b), invertase (c), $\beta$-glucosidase (d), cellulase (e), and polyphenol oxidase (f) in the surface layer $(0-10 \mathrm{~cm})$. Vertical bars denote the standard errors of the means $(n=4)$. Different letters indicate significant differences among treatments at $P<0.05$.

Fig. 4. Relationships between the cumulative $\mathrm{CO}_{2}$ emissions during $300 \mathrm{~d}$ incubation and activities of chitinase (a) and cellulase (b) in the surface layer $(0-10 \mathrm{~cm})$. Dash-dot lines indicate the bounds of the $95 \%$ confidence intervals for the regression equations.

Fig. 5. Relationships between the size of slow $\mathrm{C}$ pool $\left(C_{\mathrm{s}}\right)$ and activities of cellulase (a) and polyphenol oxidase (b) in the surface layer $(0-10 \mathrm{~cm})$. Dash-dot lines indicate the bounds of the $95 \%$ confidence intervals for the regression equations. 


\section{Table 1}

Effects of $\mathrm{N}$ and $\mathrm{P}$ additions on the soil biochemical properties and microbial metabolic quotient in the surface layer $(0-10 \mathrm{~cm})$.

\begin{tabular}{|c|c|c|c|c|}
\hline & Control & $\mathrm{N}$ & $\mathrm{P}$ & NP \\
\hline $\mathrm{pH}$ & $7.21(0.10)^{\mathrm{a}}$ & $7.11(0.18)^{\mathrm{a}}$ & $7.57(0.17)^{\mathrm{a}}$ & $7.13(0.07)^{\mathrm{a}}$ \\
\hline $\mathrm{TN}\left(\mathrm{g} \mathrm{N} \mathrm{kg}^{-1}\right)$ & $6.75(0.10)^{\mathrm{a}}$ & $6.08(0.09)^{\mathrm{b}}$ & $5.93(0.10)^{\mathrm{b}}$ & $6.10(0.08)^{b}$ \\
\hline $\mathrm{NO}_{3}{ }^{-}\left(\mathrm{mg} \mathrm{N} \mathrm{kg}^{-1}\right)$ & $22.3(1.1)^{b}$ & $40.5(5.1)^{\mathrm{a}}$ & $17.1(2.4)^{b}$ & $37.7(5.7)^{\mathrm{a}}$ \\
\hline $\mathrm{NH}_{4}^{+}\left(\mathrm{mg} \mathrm{N} \mathrm{kg}^{-1}\right)$ & $3.7(0.1)^{\mathrm{b}}$ & $3.5(0.1)^{\mathrm{b}}$ & $4.2(0.0)^{\mathrm{a}}$ & $4.1(0.2)^{\mathrm{a}}$ \\
\hline $\operatorname{DON}\left(\mathrm{mg} \mathrm{N} \mathrm{kg}^{-1}\right)$ & $33.8(0.6)^{\mathrm{b}}$ & $44.6(1.5)^{\mathrm{a}}$ & $36.4(2.7)^{\mathrm{b}}$ & $46.6(3.5)^{\mathrm{a}}$ \\
\hline $\mathrm{TP}\left(\mathrm{g} \mathrm{P} \mathrm{kg}^{-1}\right)$ & $0.79(0.01)^{\mathrm{b}}$ & $0.78(0.01)^{\mathrm{b}}$ & $0.99(0.01)^{\mathrm{a}}$ & $0.96(0.03)^{\mathrm{a}}$ \\
\hline $\mathrm{AP}\left(\mathrm{mg} \mathrm{P} \mathrm{kg}{ }^{-1}\right)$ & $7.0(0.4)^{\mathrm{b}}$ & $6.6(0.5)^{\mathrm{b}}$ & $45.3(0.9)^{\mathrm{a}}$ & $46.1(1.2)^{\mathrm{a}}$ \\
\hline TN/TP & $8.51(0.09)^{\mathrm{a}}$ & $7.85(0.09)^{\mathrm{b}}$ & $5.99(0.04)^{\mathrm{c}}$ & $6.37(0.26)^{\mathrm{c}}$ \\
\hline $\mathrm{qCO}_{2}\left(\mathrm{mg} \mathrm{CO}{ }_{2}-\mathrm{C} \mathrm{g}^{-1} \mathrm{MBC} \mathrm{h}^{-1}\right)$ & $2.52(0.14)^{b}$ & $2.39(0.08)^{b}$ & $2.93(0.14)^{\mathrm{a}}$ & $3.03(0.09)^{\mathrm{a}}$ \\
\hline
\end{tabular}

The values in parentheses represent the standard errors of the means $(n=4)$.

Different letters within the same row indicate significant differences among treatments at $P<0.05$.

SOC, soil organic $\mathrm{C}$; $\mathrm{TN}$, total $\mathrm{N}$; $\mathrm{NO}_{3}{ }^{-}$, nitrate; $\mathrm{NH}_{4}{ }^{+}$, ammonium; DON, dissolved organic N; TP, total P; AP, available P; TN/TP, the ratio of $\mathrm{TN}$ to $\mathrm{TP} ; \mathrm{qCO}_{2}$, microbial metabolic quotient. 


\section{Table 2}

Effects of $\mathrm{N}$ and $\mathrm{P}$ additions on the plant biomass and species richness.

\begin{tabular}{lllll}
\hline & Control & $\mathrm{N}$ & $\mathrm{P}$ & $\mathrm{NP}$ \\
\hline Aboveground biomass $\left(\mathrm{g} \mathrm{m}^{-2}\right)$ & $431(34)^{\mathrm{b}}$ & $662(20)^{\mathrm{a}}$ & $396(8)^{\mathrm{b}}$ & $647(26)^{\mathrm{a}}$ \\
Grasses biomass $\left(\mathrm{g} \mathrm{m}^{-2}\right)$ & $313(17)^{\mathrm{b}}$ & $482(42)^{\mathrm{a}}$ & $298(30)^{\mathrm{b}}$ & $509(33)^{\mathrm{a}}$ \\
Sedges biomass $\left(\mathrm{g} \mathrm{m}^{-2}\right)$ & $23.3(6.2)^{\mathrm{b}}$ & $39.9(5.4)^{\mathrm{a}}$ & $4.1(0.3)^{\mathrm{c}}$ & $2.8(1.9)^{\mathrm{c}}$ \\
Legumes biomass $\left(\mathrm{g} \mathrm{m}^{-2}\right)$ & $8.0(5.0)^{\mathrm{a}}$ & $4.6(2.8)^{\mathrm{a}}$ & $4.1(0.8)^{\mathrm{a}}$ & $0.6(0.2)^{\mathrm{a}}$ \\
Forbs biomass $\left(\mathrm{g} \mathrm{m}^{-2}\right)$ & $87(22)^{\mathrm{a}}$ & $136(55)^{\mathrm{a}}$ & $90(28)^{\mathrm{a}}$ & $135(15)^{\mathrm{a}}$ \\
Belowground biomass $\left(\mathrm{g} \mathrm{m}^{-2}\right)$ & $2065(232)^{\mathrm{a}}$ & $2273(255)^{\mathrm{a}}$ & $2250(252)^{\mathrm{a}}$ & $2333(230)^{\mathrm{a}}$ \\
Plant species richness & $30.0(2.5)^{\mathrm{a}}$ & $25.3(1.3)^{\mathrm{ab}}$ & $27.3(2.9)^{\mathrm{a}}$ & $19.0(0.6)^{\mathrm{b}}$ \\
\hline
\end{tabular}

The values in parentheses represent the standard errors of the means $(n=4)$.

Different letters within the same row indicate significant differences among treatments at $P<0.05$. 


\section{Table 3}

The sizes and half-lives $\left(T_{1 / 2}\right)$ of soil active $\mathrm{C}$ pool $\left(C_{\mathrm{a}}\right)$ and slow $\mathrm{C}$ pool $\left(C_{\mathrm{s}}\right)$ in the surface layer $(0-10 \mathrm{~cm})$.

\begin{tabular}{lllll}
\hline Treatment & $C_{\mathrm{a}}(\%)$ & $C_{\mathrm{s}}(\%)$ & $\left(T_{1 / 2}\right)_{\mathrm{a}}($ days $)$ & $\left(T_{1 / 2}\right)_{\mathrm{s}}($ years $)$ \\
\hline Control & $3.4(0.5)^{\mathrm{c}}$ & $96.6(0.5)^{\mathrm{a}}$ & $37.7(2.6)^{\mathrm{b}}$ & $19.9(0.5)^{\mathrm{a}}$ \\
$\mathrm{N}$ & $5.5(0.3)^{\mathrm{ab}}$ & $94.5(0.3)^{\mathrm{bc}}$ & $53.5(5.2)^{\mathrm{a}}$ & $14.9(1.4)^{\mathrm{bc}}$ \\
$\mathrm{P}$ & $6.4(0.2)^{\mathrm{a}}$ & $93.6(0.2)^{\mathrm{c}}$ & $61.5(2.0)^{\mathrm{a}}$ & $11.9(0.2)^{\mathrm{c}}$ \\
$\mathrm{NP}$ & $4.9(0.3)^{\mathrm{b}}$ & $95.1(0.3)^{\mathrm{b}}$ & $38.6(2.1)^{\mathrm{b}}$ & $16.5(2.1)^{\mathrm{ab}}$ \\
\hline
\end{tabular}

The $R^{2}$ values of the model fitting coefficient were always above 0.99 .

The values in parentheses represent the standard errors of the means $(n=4)$.

Different letters within the same column indicate significant differences among treatments at $P<0.05$. 


\section{Table 4}

Pearson correlation coefficients between soil organic $\mathrm{C}$ fractions and enzyme activities in the surface layer $(0-10 \mathrm{~cm})$.

\begin{tabular}{llllll}
\hline & SOC & DOC & EOC & ROC & MBC \\
\hline Chitinase & -0.240 & 0.220 & 0.002 & -0.107 & 0.341 \\
Acid phosphatase & 0.124 & 0.345 & 0.334 & 0.295 & -0.314 \\
Invertase & 0.011 & 0.227 & 0.205 & -0.089 & 0.077 \\
$\beta$-glucosidase & -0.376 & 0.440 & -0.212 & -0.418 & $\mathbf{0 . 6 2 0 *}$ \\
Cellulase & $-\mathbf{0 . 8 2 2 * *}$ & 0.049 & -0.478 & $-\mathbf{0 . 7 4 7 * *}$ & $\mathbf{0 . 5 3 8 *}$ \\
Polyphenol oxidase & $\mathbf{- 0 . 5 4 1 *}$ & -0.496 & -0.245 & -0.396 & 0.258 \\
\hline
\end{tabular}

Bold values indicate significant correlations at $* P<0.05$, ** $P<0.01$.

SOC, soil organic C; DOC, dissolved organic C; EOC, easily oxidized organic C;

ROC, recalcitrant organic $\mathrm{C}$; $\mathrm{MBC}$, microbial biomass $\mathrm{C}$. 


\section{Highlights}

- $\mathrm{N}$ addition increased aboveground plant biomass and decreased species richness.

- $\quad \mathrm{N}$ and $\mathrm{P}$ enrichment decreased SOC content in the surface layer by reducing recalcitrant organic $\mathrm{C}$ content and slow $\mathrm{C}$ pool.

- Microbial biomass and activities of $\mathrm{C}$-degrading and $\mathrm{N}$-degrading enzymes were increased after $\mathrm{N}$ and $\mathrm{P}$ input.

- Activities of cellulase and chitinase were positively correlated with $\mathrm{CO}_{2}$ emissions.

- Soil slow $\mathrm{C}$ pool had a negative correlation with activities of cellulase and polyphenol oxidase. 


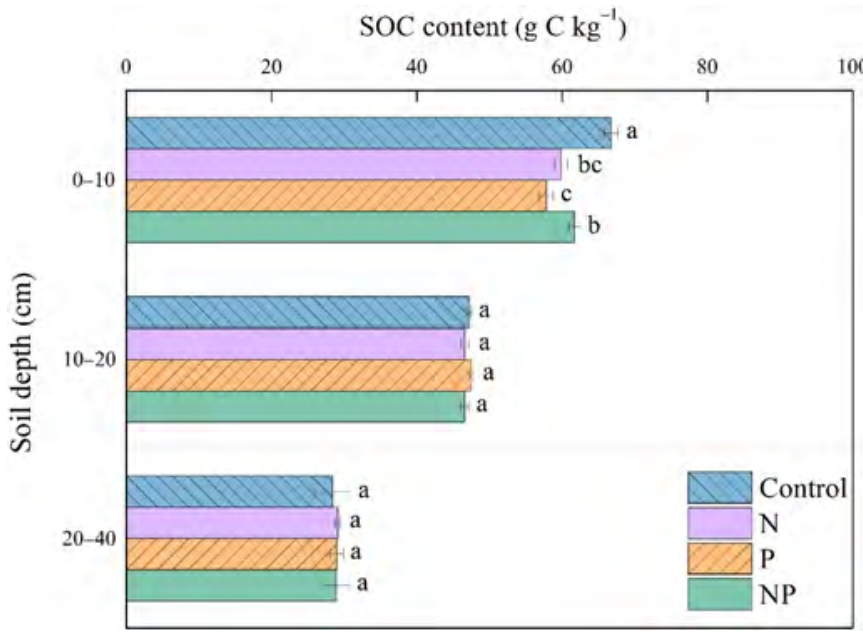

Figure 1 


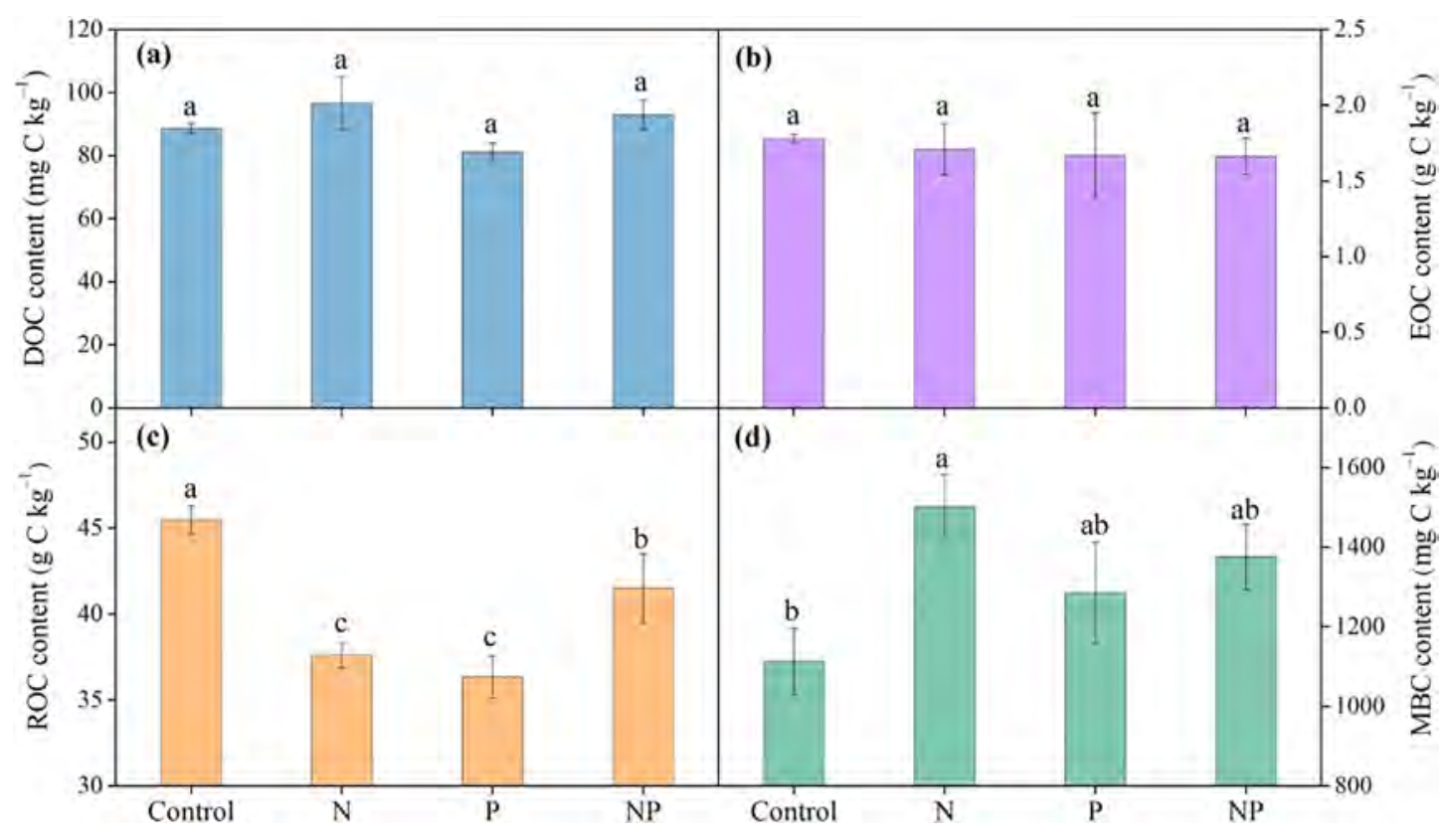

Figure 2 


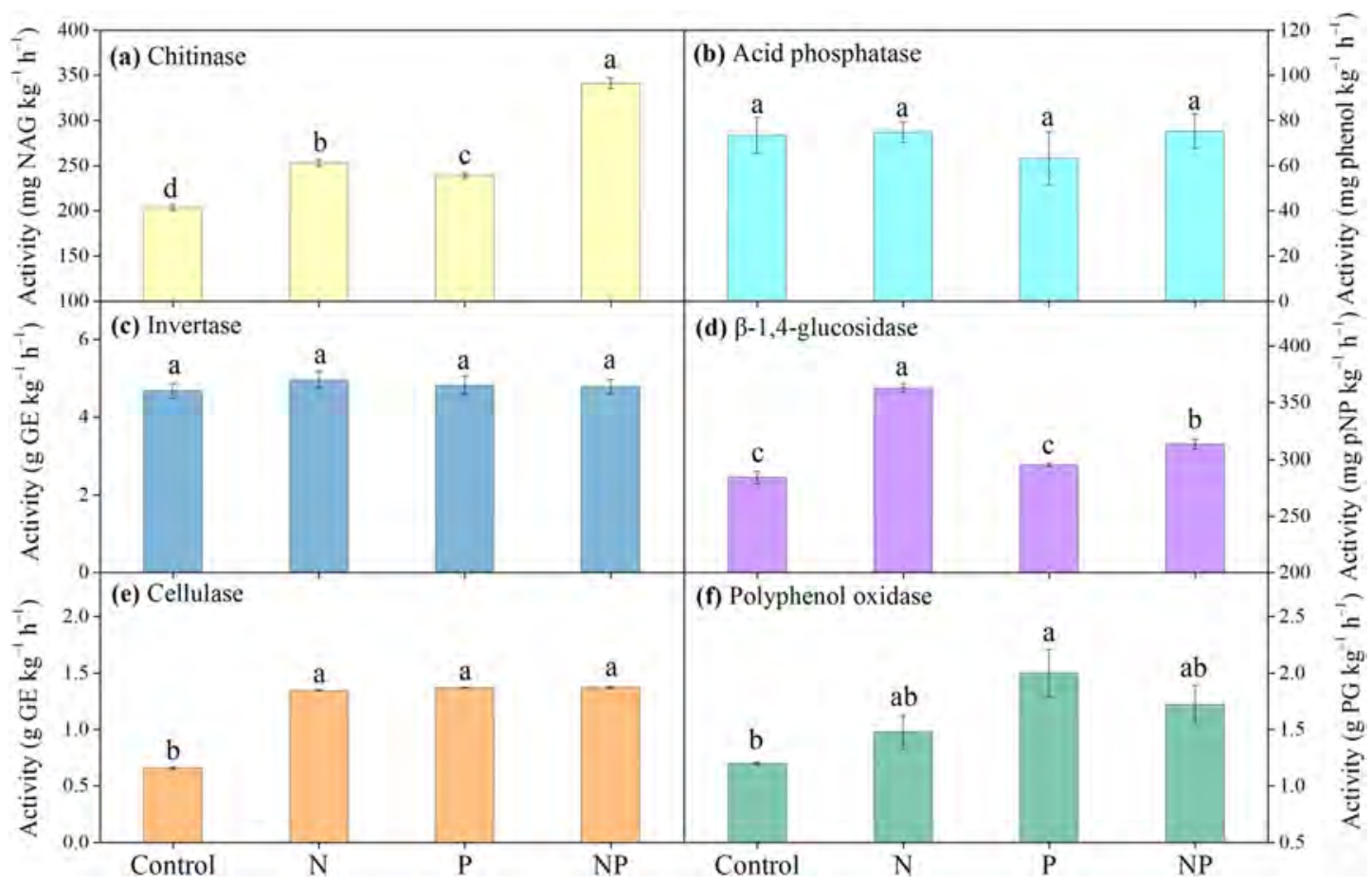

Figure 3 


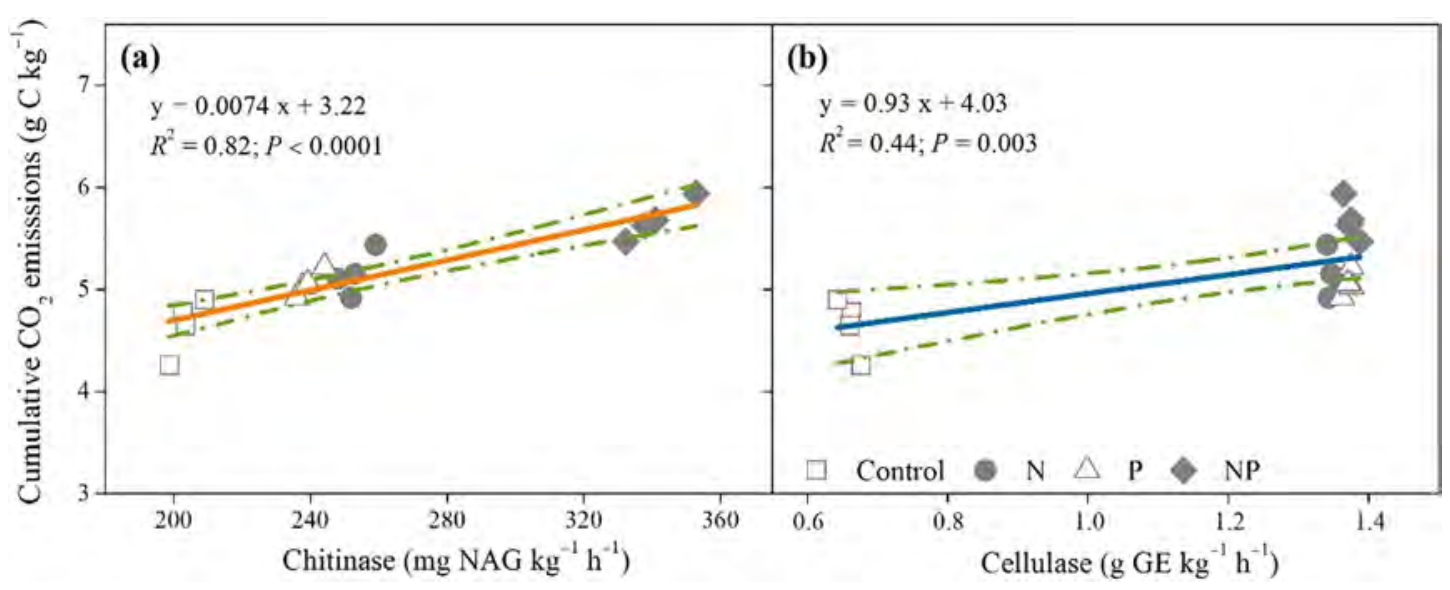

Figure 4 


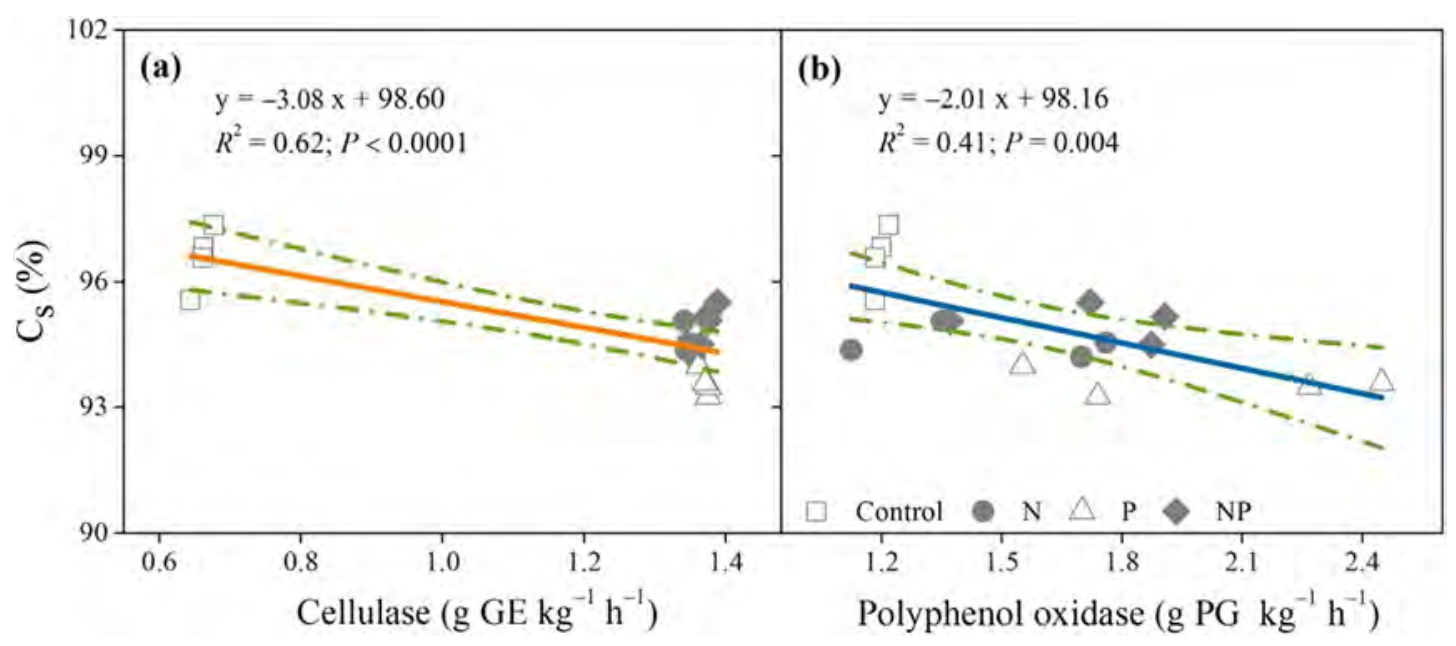

Figure 5 